\title{
English in the linguistic landscape of Thailand: A case study of public signs in Hat Yai
}

\author{
Ana Cristina Vivas-Peraza \\ avivasperaza@unizar.es \\ University of Zaragoza, Spain
}

\begin{abstract}
During the last decades, English has become an international language in all kinds of contexts, including business and tourism, and Asian linguistic landscapes are a good reflection of this phenomenon. This paper focuses on Thailand and the city of Hat Yai, where a corpus of 165 public signs were collected. These were analysed quantitatively to discuss the functions that English performs in public domains, and also qualitatively, by means of a multimodal analysis, to observe the Thai and English prominence in the case of multilingual signs. The results show the importance of English, not only as an international communicative tool, but also as a language of prestige and media impact. Furthermore, some features of written Thai English or Tinglish were found in some signs, which may confirm the early stages of development of a possible new emerging variety of World Englishes.
\end{abstract}

Keywords: Linguistic Landscape; Thailand; Hat Yai; Functions of English, Language Prominence; Thai English.

\section{INTRODUCTION}

Linguistic Landscape (henceforth LL) research is defined by Landry and Bourhis (1997) as the study of "the visibility and salience of languages on public and commercial signs in a given territory or region" (p. 23); that is to say, it involves the study of the presence and dominance of languages displayed in the public domains of a particular location. These languages are to be found in written signs "outside private homes", such as "road signs, names of streets, shops and schools" (Shohamy et al., 2010, p.xiv), and it can also be extended to advertisements and even product names.

Thailand has been a very attractive destination for LL researchers, given the prominent economic growth that the country has experienced thanks to tourism during the last decade, and therefore, the impact that this phenomenon has had on the language exposure and usage. Ever since Huebner (2006) explored 15 neighbourhoods in Bangkok, other relevant studies have followed, such as Thongton's (2016) in Chiang Mai, and Prasert and Zilli's (2019) in Pattaya. Nonetheless, all these studies have been carried out in the capital or in popular tourist urban areas of the country, and little 
attention has been paid to other cities that are not especially well-known, such as Hat Yai.

Hat Yai is the fourth largest city of Thailand, located in the Southeast, so that it is a transit location for travellers who pass through and from Malaysia, its neighbouring country. Most tourists it receives are of Malaysian and Singaporean origin, and the presence of Western people is not very common. The English language is not as widely spoken as in other tourist-destined locations such as Chiang Mai, Bangkok and Phuket; nevertheless, its presence on the public signage is notorious and worth examining.

Undoubtedly, English has become a global language during the past decades, and its use in the LL of Hat Yai can be primarily justified by the need of communicating with tourists and expats of any origin. Some public signs in this city, however, prove that on many occasions, the choice is linked to a question of language prestige and globalisation. The choices made in terms of visual prominence of one language or another on those signs may reveal those functions. Moreover, it is worth mentioning that quite a few signs written in English by Thai authors do not adopt any specific standard variety of English, such as the Australian or the British. What at first sight may be considered a poor use of grammar and vocabulary, reflects that a new potential variety of English, known as Thai English or Tinglish (Bennui \& Hassim, 2014, p. 16), may be developing. Together with the use of English as the international language for communication (p. 14), ThaiE is slowly spreading, and the LL of Hat Yai shows it.

This article will therefore focus on the specific functions that the English language performs in the public sphere of Hat Yai, the visual prominence of this language in the case of multilingual signs, and the incidence of signs written in ThaiE. These aims have been summarised in the following research questions:

(i) What are the most frequent functions of English in the LL of Hat Yai?

(ii) How visually prominent English is on signs, and what part of the message is translated into English?

(iii) How prevailing is the use of ThaiE in signs and which are its features?

These questions will be answered by gathering and analysing some data that (i) include public signs belonging to different domains, and therefore, carry out different functions; 
(ii) contain several multilingual signs that can display the preference for visual prominence of English in relation to Thai and other languages and the amount of information that is provided in those languages; and (iii) display, where applicable, some features of ThaiE.

\section{LITERATURE REVIEW}

\section{II.1. Previous LL Studies}

The notion of LL constitutes a relatively recent or "fertile" area of study in the field of sociolinguistics (Shohamy \& Gorter, 2009, p.14). Even though a few early works already explored the choice of languages displayed in public scenarios, like that of Spolsky and Cooper (1991) in Jerusalem, the concept of LL was not introduced until 1997 by Landry and Bourhis. Since then, relevant works have been compiled and edited by well-known scholars, such as Gorter (2006) and Shohamy et al. (2010), in their respective books: Linguistic Landscape. A New Approach to Multilingualism, and Linguistic Landscape of the City.

The scope of study is large and diverse. Some researchers have analysed the language choice in shop signs, like Wang (2013) did in Beijing and Amer and Obeidat (2014) accomplished in Aqaba City. Others have centred on the promotion of multilingualism through landscapes, such as Dressler's (2015) work in a public school with Germanbilingual program and Siricharoen's (2016) at Chulalongkorn University in Bangkok. There are also those who have engaged in a discussion on the presence of the English language in the public sphere and have therefore been an inspiration and a source of theoretical and practical proposals for the present analysis. For instance, Lawrence (2012) analysed the use of English in the LL of Korea and its impact on the national language, and Takhtarova et al. (2015) examined the role of English as an international language in the cities of Paris, Berlin, and Kazan.

\section{II.2. Actors and Functions of Public Signs}

Most scholars, like Backhaus (2007), Shohamy and Gorter (2009), and Coulmas (2013), agree that the target location for analysis is the urban environment, for most written 
signs are exposed there. Depending on the LL actors (i.e., the authors who shape the LL), Ben-Rafael et al. (2006) classify signs into two groups: public actors, or "topdown", and private actors, or "bottom-up". The former consists in "official signs placed by the government or related institution" and the latter refers to "non-official signs put there by commercial enterprises, organisations or persons" (p. 3). In any case, written signs are created by city residents for the public (local or non-local) to see; thus, the language choice in them is not random.

The LL of a city provides information about the history, ideology, political system, economy, geography, and demography of the society. It also projects values like "patriotism, national pride, ethnic allegiance, commercial competition and globalisation" (Shohamy et al., 2010, p.xiii), which unfold some functions of multilingualism in public writing. Additionally, apart from communicating, a LL also aims to transmit messages to its readers and its study is fundamental to understand the background and current behaviour of a community. At the same time, it may be as powerful as to lead to changes in society (Coulmas, 2013): it can serve as a tool for protest, media broadcast or diffusion, and even language input.

According to Landry and Bourhis (1997), there are two major functions of public signs: informational and symbolic. The informational function aims at indicating the geographical territory of a language group and the symbolic function reveals how different languages are perceived by a particular linguistic community in terms of their value and status. When dealing with English language use in a particular LL, another function could be considered: media diffusion. In this current era of digital globalisation, with English as the dominant language over the internet (Flammia \& Saunders, 2007), it is noticeable that the English language may also be used to broadcast certain information faster than it would be done with another language, and this may also be displayed through the LL.

\section{II.3. Choices about Language Prominence in Public Signs}

The positioning and the spatial appearance of a language in a public sign is also an aspect that some other LL experts (Haynes, 2012; Huebner, 2006) have shown awareness of in the study of linguistic landscapes, since it provides significant 
information about the power and relevance of such language in a community of speakers or in a particular domain. In his article, Huebner (2006) explores language prominence in the linguistic landscape of Bangkok, and Haynes (2012) also compares the positioning of English and Welsh in signs in the city of Cardiff.

According to Huebner (2006), language prominence depends on: (i) placement of text, or primary or secondary position that the language occupies on the sign; (ii) size of font; (iii) amount of text provided in a particular language in comparison to another; and (iv) colours of font or surrounding design around the text.

Together with language prominence, another interesting aspect is the amount of text that is devoted to each language in multilingual signs, as all the content of the message is not always provided in both languages. According to Reh's (2004) classification of multilingual signs, there are 4 types of relationship between the content of the message and the languages used in the signs: duplicating (all information is provided in each language), fragmentary (one language provides more information than others), overlapping (two or more languages present shared information in the sign, but each of them also provide other details not found in the other languages) and complementary (two or more languages show different information).

\section{II.4. The English Language in Thailand}

Unlike most Southeast Asian countries, Thailand always managed to avoid colonialism from any European empire (Baker, 2012), and standard Thai has always been the only official language of the country. Bolton (2008) affirms that only around $10 \%$ of the Thai population are English speakers and according to Kachru's (1985) Three circles of English theory, Thailand is included in the 'Expanding circle' of World Englishes (see Figure 1), where "English plays no historical or governmental role" (Wilang \& Teo, 2012, p.4). 


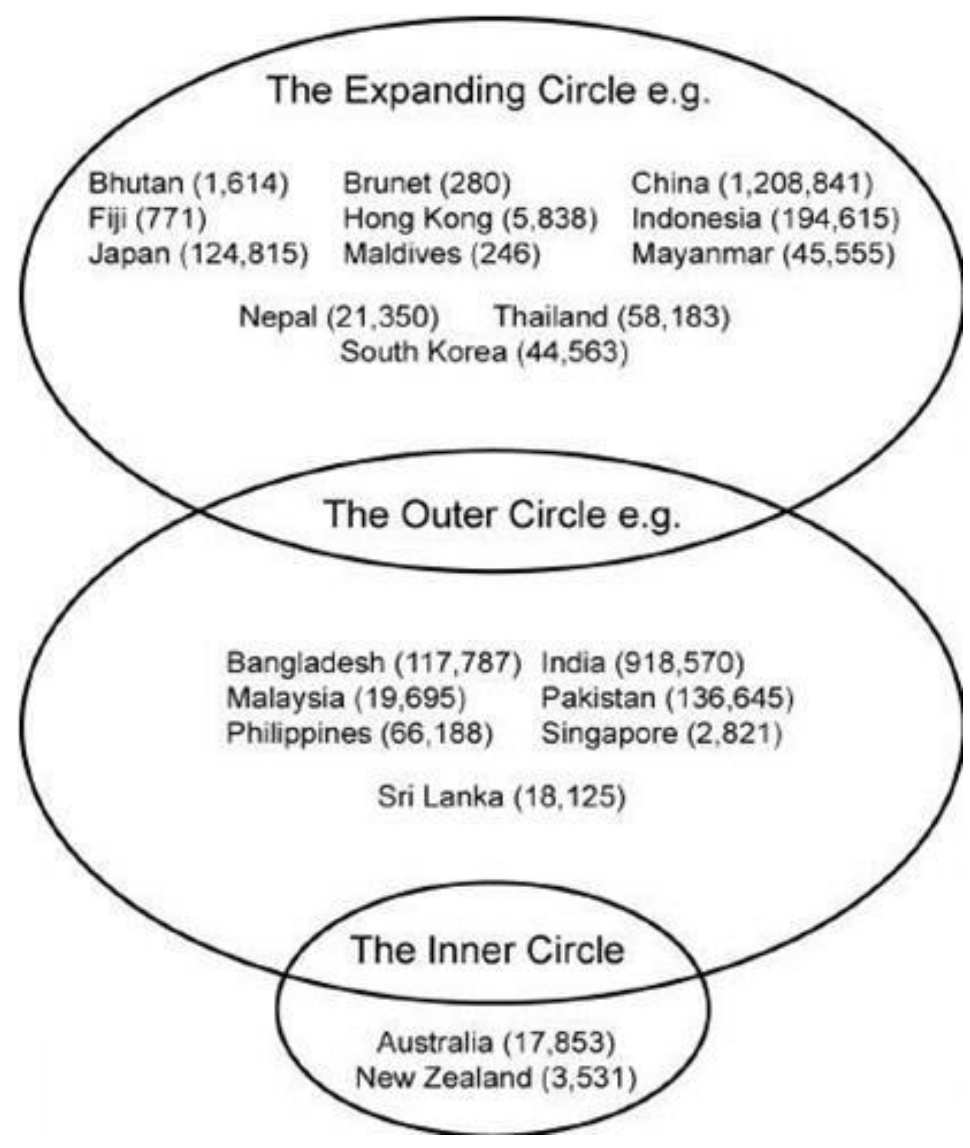

Figure 1. Three Concentric Circles of Asian Englishes (Populations in Thousands) (Kachru, 1998, p. 94).

Conversely, while the presence of English in Thai people's daily lives is rare, it does play an important role in international communication and digital technology these days, and it is regarded as a language of prestige and professionalism. It constitutes the means of communication with not only the Western world, but also with other Asian countries: it is the common tongue in $\operatorname{ASEAN}^{\mathrm{i}}$ and ASEAN+3 ${ }^{\mathrm{ii}}$ (Baker, 2012). In addition, as the field of World Englishes evolves, and English usage is slowly spreading around the country, ThaiE is emerging as a new English variety (Chutisilp, 1984; Watkhaolarm, 2005).

\section{METHODOLOGY}

\section{III.1. Materials}

For this project, 165 pictures of public signs where English was included were taken randomly. 35 signs were monolingual (only written in English) and the remaining 130 
signs were multilingual, where more than one language appeared: 123 were written in English and Thai, 3 in English and Chinese, 2 in English, Thai and Chinese, and 2 in English, Japanese and Thai.

To collect a diverse sample and to compare the linguistic behaviour of different landscapes around the Hat Yai, the following locations were chosen:

1. Prince of Songkla University Campus, with address Kanjanawanich Soi ${ }^{\mathrm{iii}}$ 15 Rd, Tambon ${ }^{\text {iv }}$ Kho Hong, Amphoe ${ }^{v}$ Hat Yai, Changwat ${ }^{\text {vi }}$ Songkla 90110.

2. Central Festival Shopping Centre, with address Kanjanawanich Rd, Hat Yai.

3. Vongvanit Rd, Tambon Hat Yai, Amphoe Hat Yai, Chang Wat Songkla 90110.

4. Thumnoonvithi $\mathrm{Rd}$, Tambon Hat Yai, Amphoe Hat Yai, Changwat Songkla, 90110.

These areas can be classified into three domains: education (university campus), commerce (shopping centre) and the public way (the two streets chosen at random). For obtaining a balanced collection of signs, I took the same number of pictures for each of them; namely, 55 signs at PSU campus, 55 at Central Festival, and another 55 at the streets Thumnoonvithi and Vongvanit.

There is no general consensus on what signs can be representative of the LL, since several points of view have been provided (Shohamy \& Gorter, 2009). Landry and Bourhis (1997) would consider roads and street signing, advertisements and public signs in official buildings, whereas Backhaus (2006) would select "any piece of written text within a definable frame" (p.56). During the analysis of signs in Hat Yai, I used Backhaus's definition, selecting every sample of writing publicly displayed, not only outdoors but also inside buildings and businesses open to the public, like book covers and names of products. 


\section{III.2. Methods of analysis}

The study was conducted using a mixed methods approach, which combines quantitative and qualitative data to give an answer to the previous research questions. Quantitative analysis was used to provide an illustrative idea (in percentages) of the most common functions of English in signs, as well the visual and linguistic prominence in English and Thai and the incidence of signs displaying ThaiE features. The signs were first counted and categorised according to type (advertisement, book cover, shop sign, and so on) and actor (private or public), to facilitate the discussion around functions and language prominence depending on those categorisations. In order to discuss the functions that the English language performs, every item of the collected data was thoroughly observed and then classified according to informational, symbolic and media diffusion functions. As for the qualitative content, it consisted of a multimodal analysis to interpret the visual prominence of English and Thai in signs and to analyse the amount of text provided in each language. Huebner's (2006) and Reh's (2004) frameworks (previously developed in the literature review) were used respectively for these studies. ThaiE features in signs were contrasted to those listed in previous literature (Snodin, 2014; Thammawan, 2008; Trakulkasemsuk, 2012).

\section{IV.ANALYSIS OF THE LINGUISTIC LANDSCAPE OF HAT YAI: FINDINGS}

\section{IV.1. Categorisation of signs}

The following sign types were obtained:

- 59 advertisements (products, events, courses, etc.).

- 40 informative signs (opening hours, warning signs, instructions, directions, requests, and greetings).

- 29 shop signs.

- 14 street and place signs.

- 12 book and magazine covers, taken at $B 2 S$ stationery store, located inside Central Festival shopping centre.

- $\quad 7$ Thai products found in a 7 Eleven supermarket in Vongvanit Road. 
- 4 objects, such as a phone box or a letterbox, also contemplated by Spolsky and Cooper (as cited in Shohamy \& Gorter, 2009).

The data were also classified according to the actor: the sample provided 57 signs set in public institutions (top-down) and 108 signs created by private actors (bottom-up). Topdown signs were mostly found in PSU campus and its nature was informative in large part, whereas the majority of bottom-up sign included advertisements, found in commercial private establishments such as Central Festival. In the streets, the selected signs were mainly taken at private institutions too, which contributed to the final higher proportion of private $(65 \%)$ versus public actor signs $(35 \%)$.

\section{IV.2. Functions of English}

The incidence of each function was provided in percentages rounded up to the nearest integer number. In short, the functions of English in signs, as previously mentioned in the literature review, were classified as: informational, symbolic and media diffusion (See Table 1). Many signs were included in more than one classification, since it was determined that the use of English in them had more than one function; therefore, the sum of the percentages was higher than 100 as these multifunctional signs were counted more than once.

Table 1. Incidence of the Different English Functions in the LL of Hat Yai.

\begin{tabular}{|c|c|c|}
\hline Functions of English & $\begin{array}{c}\text { Number of signs performing } \\
\text { this function }\end{array}$ & $\begin{array}{c}\text { \% of signs performing this } \\
\text { function }\end{array}$ \\
\hline Symbolic & $93 / 165^{*}$ & $56 \%$ \\
\hline Informational & $85 / 165$ & $51 \%$ \\
\hline Media diffusion & $23 / 165$ & $14 \%$ \\
\hline
\end{tabular}

* Total number of signs

\section{IV.2.1. Informational function}

The type of signs fulfilling this function are advertisements, and more predominantly, those signs that provide what Karapalo (2011) considers as "non-commercial" information (p.32): greetings, instructions, directions, opening hour signs, place names, 
mandatory requests, objects, and warnings. All these include English and Thai (sometimes other languages as well) since they aim to address the message not only to local people, but also to foreigners, as exemplified in the Figures 2 and 3 below:

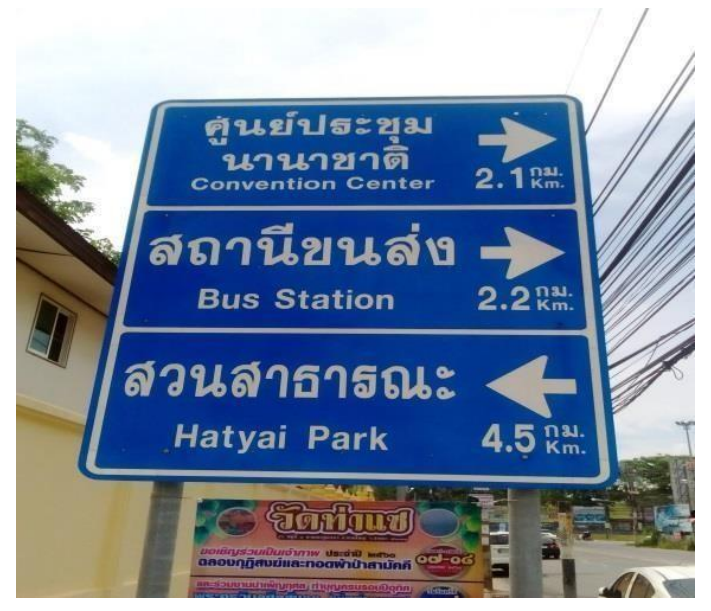

Figure 2. Road signs.

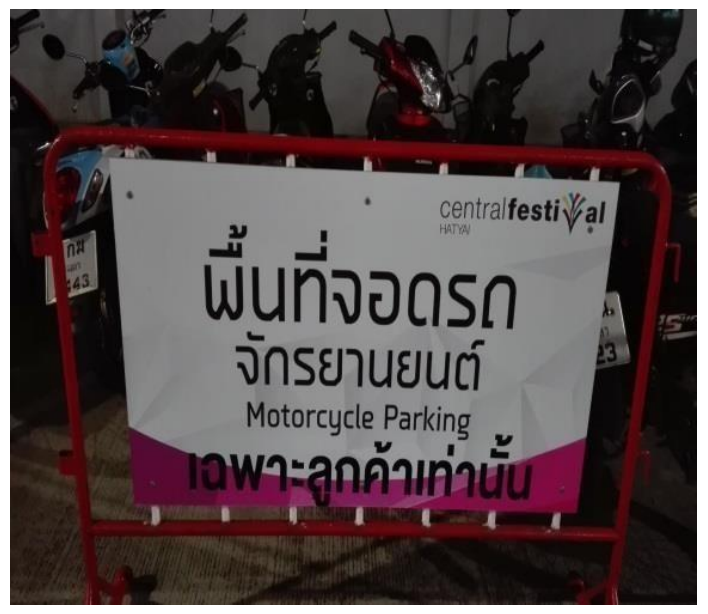

Figure 3. Motorcycle Parking.

There are also those signs in which the Thai language is not present, for they are intended only to newcomers (See Figures 4 and 5):

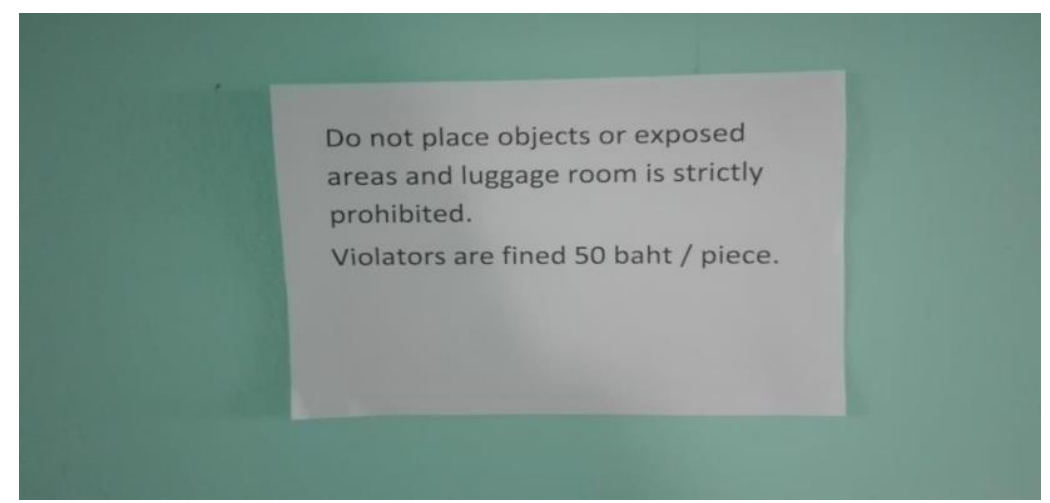

Figure 4. Warning to PSU International Students.

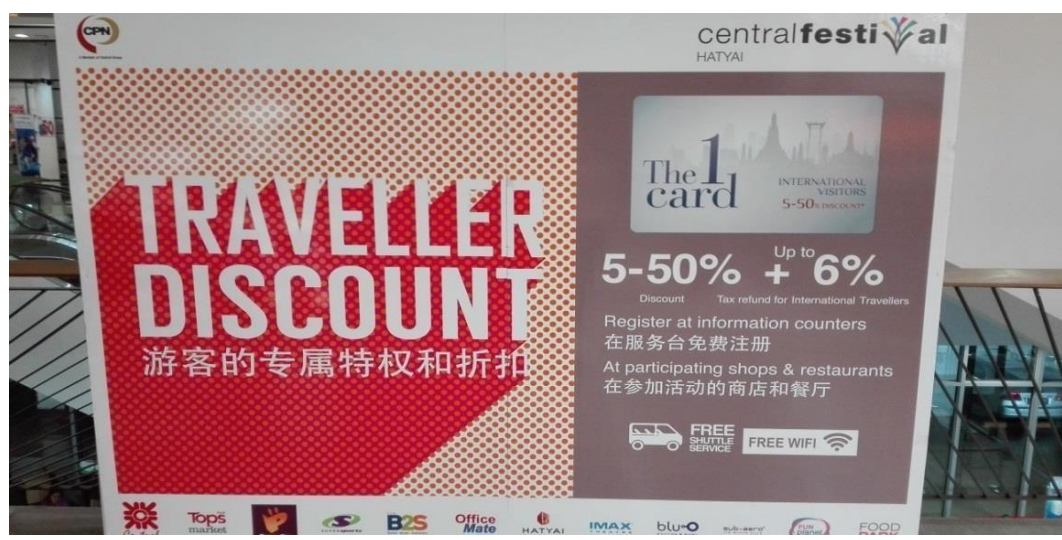

Figure 5. Advertising of Tourist Member Card at Central Festival. 
Figure 3 consists of a warning sign found in a students' dormitory inside PSU campus where only international students were hosted, and Figure 4 shows an advertisement that was located at Central Festival, in which a shopping discount membership card only for tourists is promoted. In this advertisement, the sentence "Register at information counters", on the left-hand side of the sign, may want to indicate that an English speaker is available at the counter in case international visitors wish to obtain more information about the member card.

The informational goal of English was mainly found at PSU campus with 40 signs. This is explained by the number of international students accommodated in the campus at that moment (more than 300, as stated by Ana Maria Pavel, secretary of the International Affairs Office at PSU campus) to whom the signs were addressed. As for the streets and the shopping centre, 29 and 15 signs were related to it, respectively.

\section{IV.2.2. Symbolic function}

As Bierma (2008) explains, many shops, restaurants and any type of businesses choose a foreign tongue for their names, slogans, or promotional texts. In these cases, the language choice is not motivated by the presence of foreigners, but by the positive associations that such language is presumed to evoke.

In the case of English, numerous LL researchers (Lawrence, 2012; Mensel et al., 2016; Snodin, 2014) assure that it makes products or businesses more attractive, since it carries a series of positive connotations: modernity, progress, prestige, wealth, technological development, sophistication, reliability, globalisation, success and exclusiveness. Moreover, Siricharoen (2016) also affirms that the use of English may be motivated by its aesthetic value, since its font is considered to have a minimalist style.

Consequently, many advertisements display some parts of the text in English, being normally the name of the product or business, to attract customers' attention, and then turn to Thai for explaining the characteristics of the product, as in the case of Hi-Precise Eye Pen (See Figure 6). 


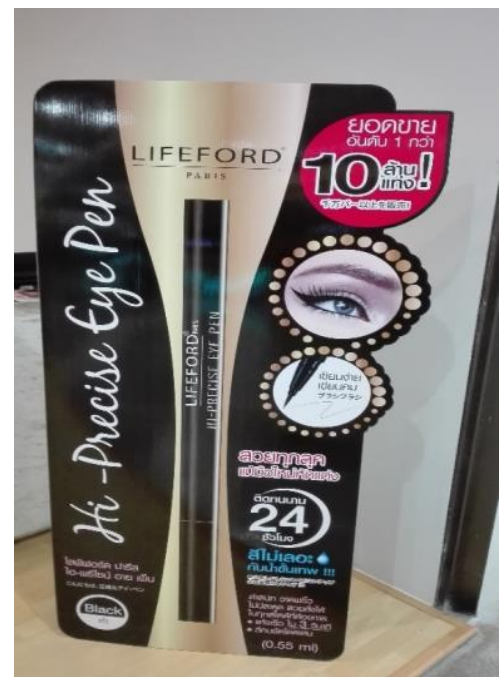

Figure 6. Advert of eyeliner.

The symbolic function was mainly found in the signs located in the Central Festival shopping centre (47 signs), and the streets Thumnoonvithi and Vongvanit (38 signs), where most advertisements, businesses and products were found.

\section{IV.2.3. Media diffusion function}

When discussing LL research and my findings with Dr. Premin Karavi, a Thai professor of the Faculty of Liberal Arts in PSU, he made me reflect about the media diffusion function of English in the LL of Hat Yai. Apart from the informational and symbolic functions, signs in Thailand prove to carry other purposes when written in English, as in Figure 7:

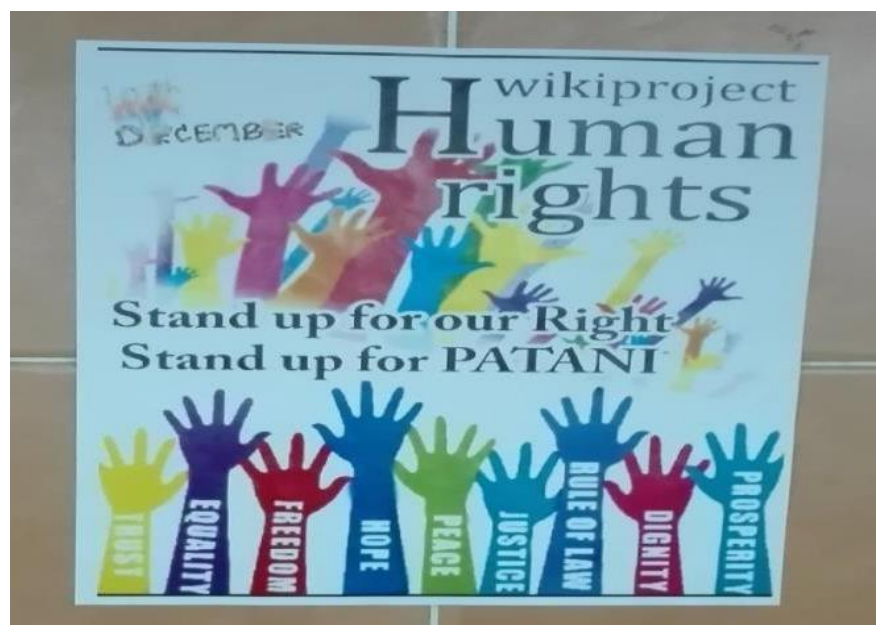

Figure 7. Claiming Independence in Patani. 
This sign, for example, aims to mobilise people to support the old Sultanate of Patani, under Bangkok's administrative control since the early $20^{\text {th }}$ century, in its fight for independence from the country ${ }^{\mathrm{vii}}$. Here, there is an informational function for its readers, but the use of English does not seem to pursue any symbolic goal; instead, it may intend to favour the media dissemination of the message, since it announces a wikiproject that is stored on the internet, and that everyone can check and circulate easily. It is worth arguing as well that English writing in this case may be used as means of resistance against the imposition of the Thai language in that area; and at the same time, to reach outsiders who presumably do not speak the local language, and therefore, shed light on the readers to whom the message may be addressed.

Given the strong dominance that English has over the mass media, especially on the Internet, some actors may use it on their signs to promote businesses, products, or events internationally. Thus, this function may also explain why Thai writers decide to write their books' titles in English even though the full content is written in Thai, business owners and suppliers choose an English name for their shops or products, and some adverts of events only include their name in English, as illustrated below (See Figures 8, 9, 10, 11, 12, 13):

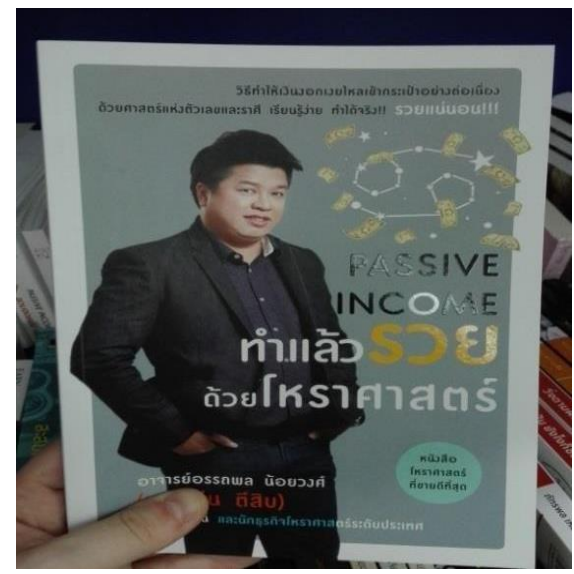

Figure 8. Passive Income.

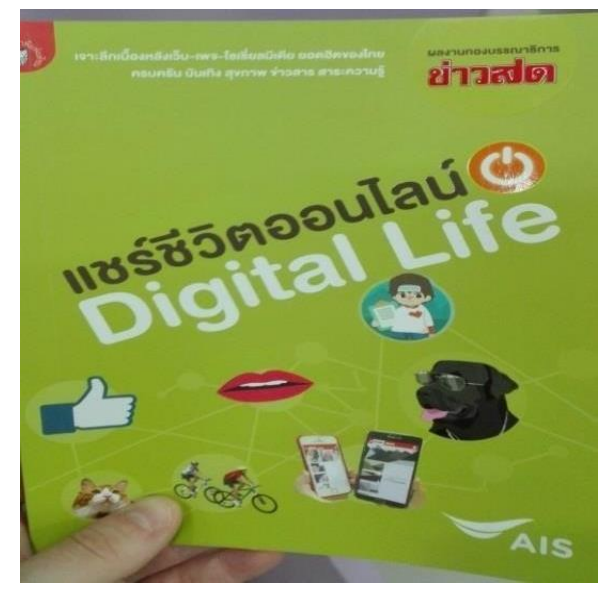

Figure 9. Digital Life book. 


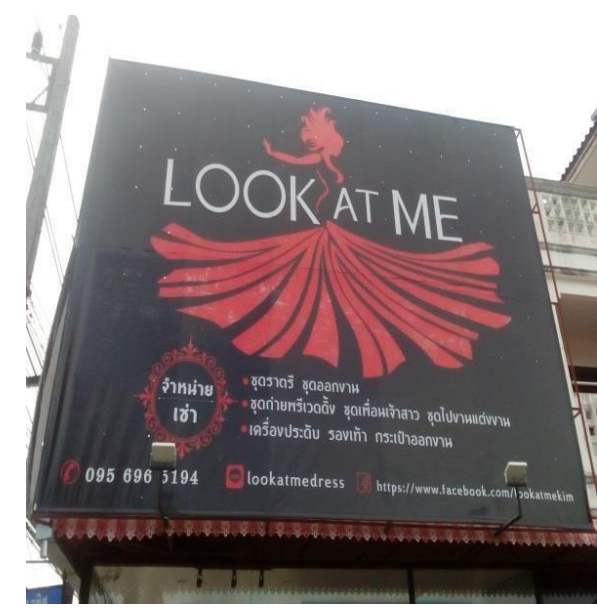

Figure 10. Look at Me.

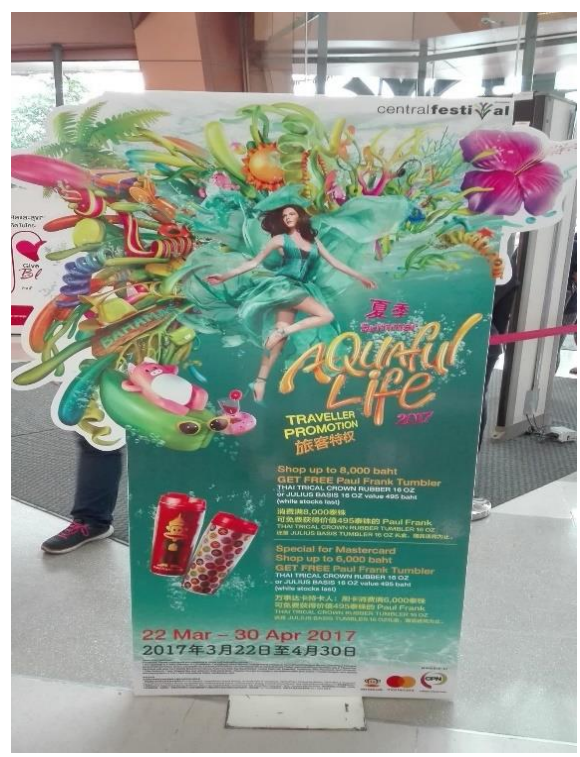

Figure 12. Aquaful life 2017.

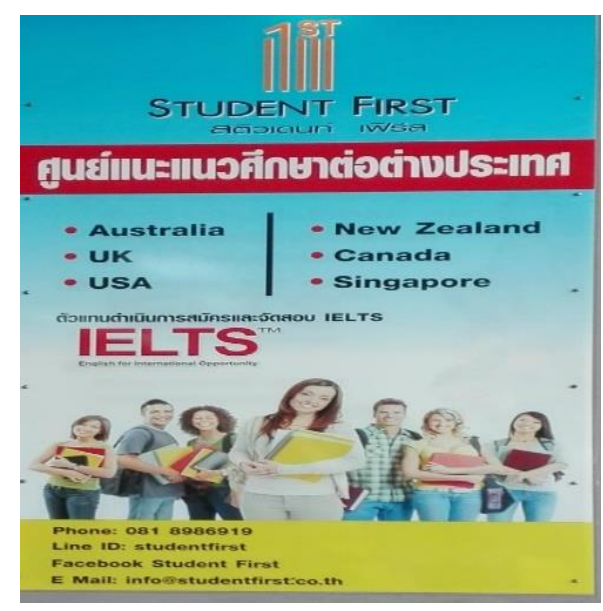

Figure 11. Student First Academy.

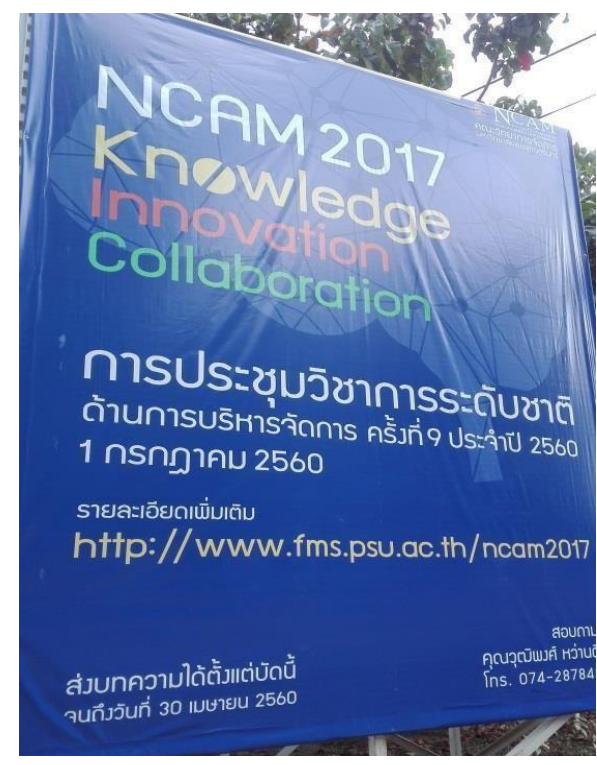

Figure 13. NCAM 2017.

It can be confusing to see so many adverts where the relevant information is written in Thai and only the title of the event, book, business, or product is provided in English. If the function of English here were informational, the whole message (or a higher proportion of it) would be provided in this language, as it is displayed in, for instance, Figures 1 and 2, where the function is merely informative for those who encounter the sign physically.

If, on the contrary, the actors of this LL provided the whole message (titles included) in Thai, the content would only be understood by the local Thai speaking public that came across the sign. The media diffusion function may provide a tentative explanation for this phenomenon: the use of English in the titles of events, products and promotions 
may facilitate their diffusion on the digital environment since the viewers can do internet search to obtain more information about them. Sometimes, as it is the case of Figures 10, 11 and 13, the signs even include internet links (which are always in English) that may make this function more explicit.

In brief, 23 signs were considered to perform the media diffusion function: 12 at Central Festival, 8 inside PSU Campus and 3 in the streets. What most of them have in common is that the main information of the sign is written in the Thai language and the title of the event, book, business, or product is produced in English, so that it can be spread more easily through the media.

\section{IV.3. Language Prominence}

Following Huebner's (2006) framework, the language prominence between English and Thai in signs was noticed and exemplified according to each variable:

- $\quad$ Placement of text. It refers to the primary or secondary position of the language in the sign. If one language appears above the other in a vertical position, the former could be considered prominent, and the same would occur if considering the horizontal perspective, that one language would be positioned first (See Figures 14 and 15).

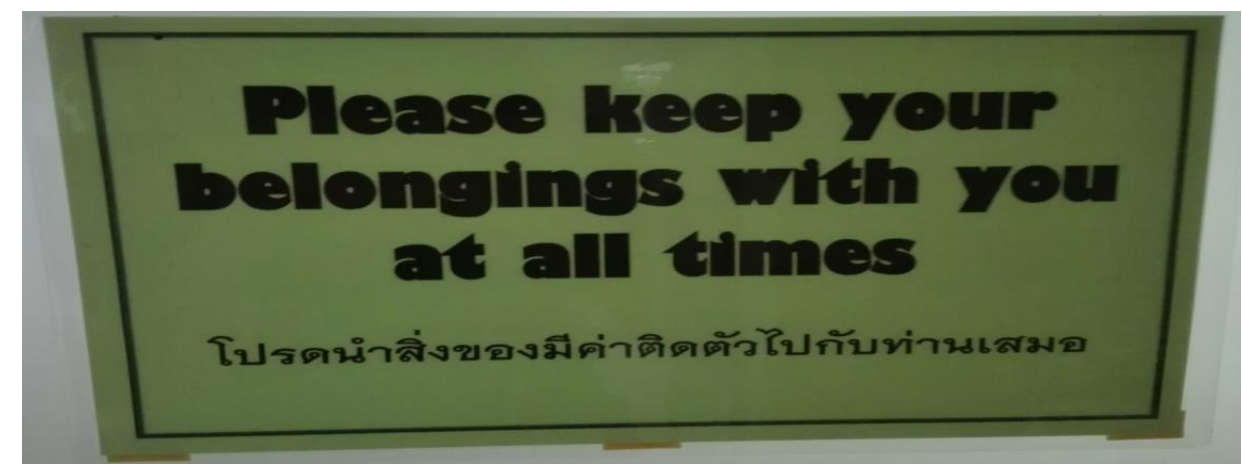

Figure 14. Warning about belongings. 


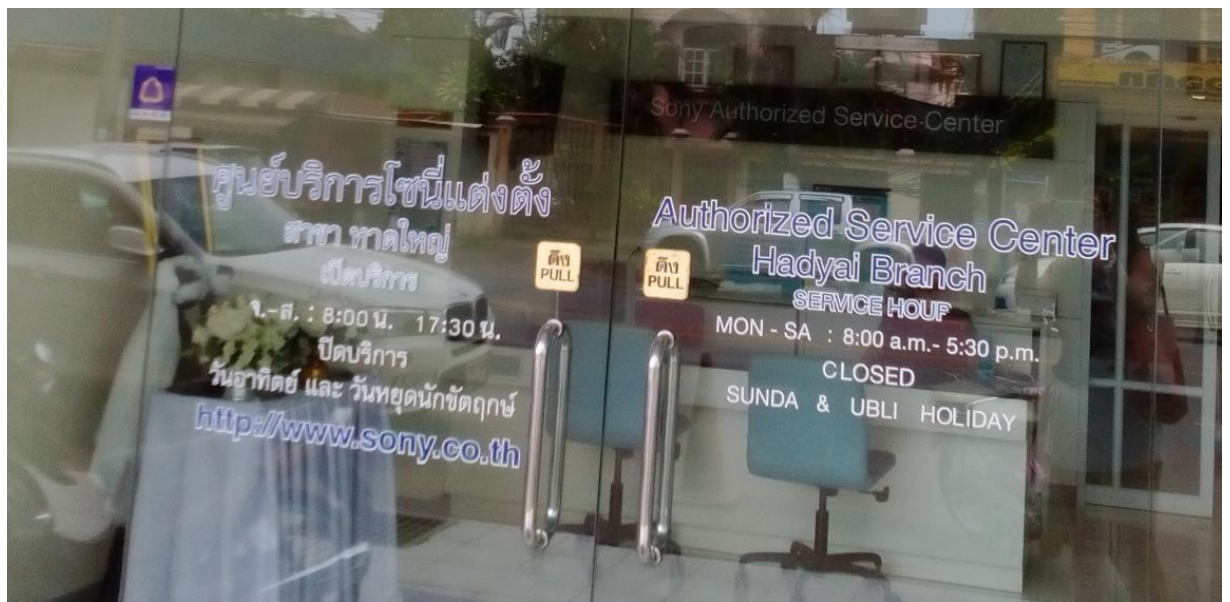

Figure 15. Opening Hours SONY shop.

It should be stressed that in Figure 14, the dominant language is English, for it is placed above Thai, and by contrast, Thai prevails over English in Figure 15, since it can be found on the left-side door of the shop ${ }^{\text {viii }}$.

- $\quad$ Size of Font. The more visible the language is in terms of letter size, the more prominent it will be meant to be in the sign. Sometimes size of font may overrule the position or placement; that is to say, a language can appear in the second position (on the right or under the other language) but be dominant because the font size used is relatively bigger, and therefore, more eye-catching (See Figure 16).

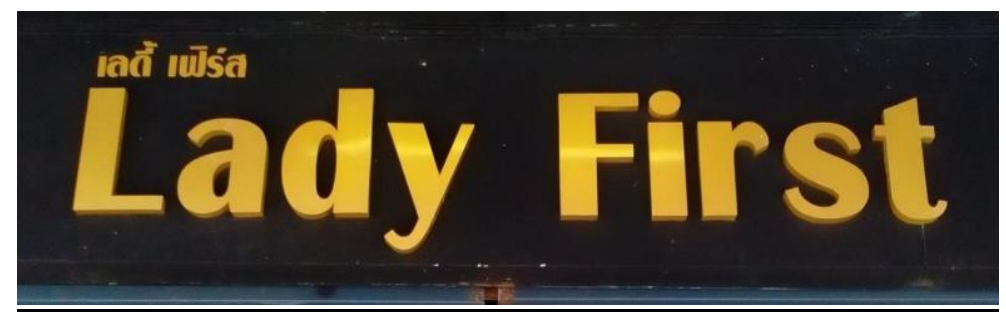

Figure 16. Lady First shop.

In Figure 16, even though Thai occupies the first vertical position, English is obviously the dominant language selected for the name of this clothes shop.

- $\quad$ Amount of Text. It can also be argued that the language prominence is determined by the text quantity. In this case, the prevailing language will be the one in which most text or the most important information of the sign has been written. Here, the choice of dominant language for analysis 
may be rather subjective, since this will depend on the information of the sign that the reader considers to be most relevant. As a proficient English speaker with no knowledge of Thai, I had to ask for translations to make decisions here. In Figure 17, for instance, I regarded that English was not the dominant language: although the acronym "IELTS", which could be working as a logo for branding purposes, is the most visually appealing message of the advert, all the information about the preparation course for this English test appears in Thai, and I considered that to be the most important part of the message.

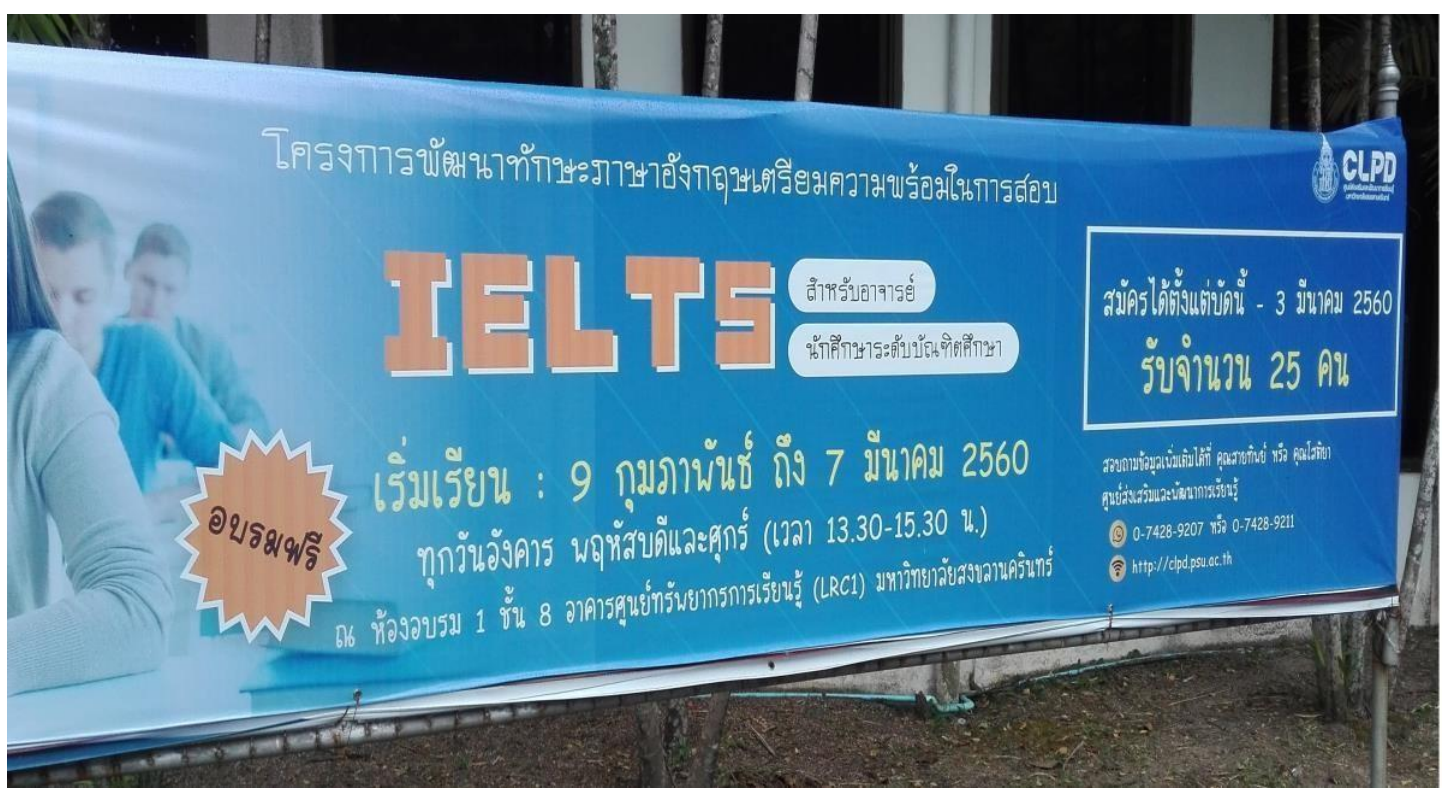

Figure 17. IELTS Preparation Course.

In contrast, in Figure 18, English seems to carry the most important information of the advertisement: "SALE 30-50\%". Even if the description of the available products and services are written in Thai, I considered the main point of the advertisement to be the interesting discounts that could be found in the shop, since the products are also illustrated by images. 


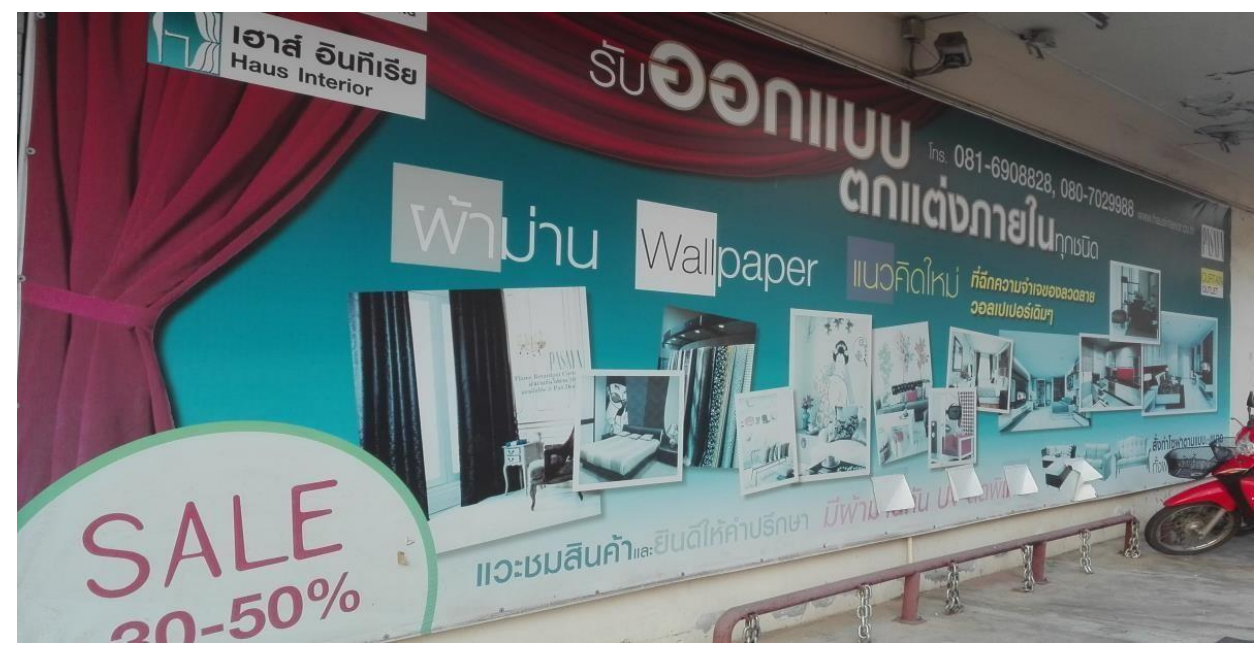

Figure 18. Haus Interior Sales.

- $\quad$ Colours. A language can also stand out from the others depending on the colour used for the font or the image or design over which the text is written. In Figure 19, even though most of the text is written in Thai, the language that prevails visually is English, not only because of the font size, but because of the golden colour in which the text was written.

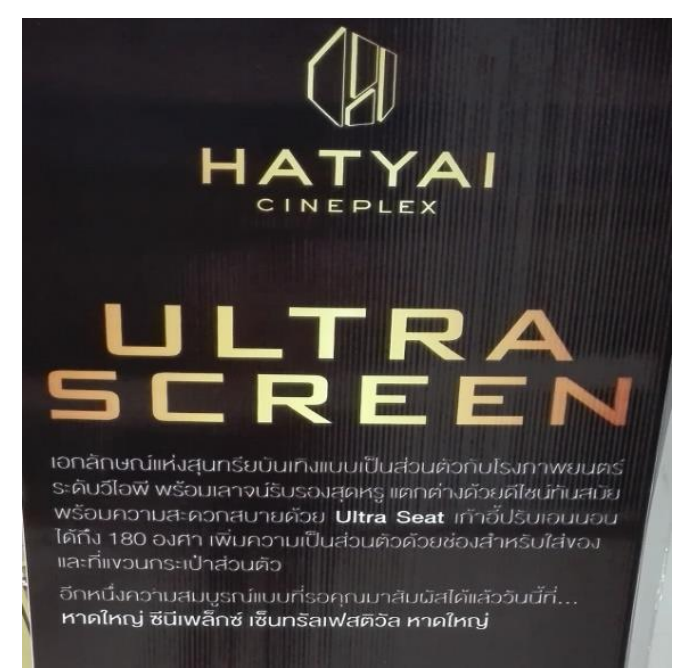

Figure 19. Ultra Screen Ad.

Regarding Figure 20, the fact that the Thai language is positioned first vertically does not prevent English from being the dominant language of the sign thanks to the blue textbox on which the text was situated. 


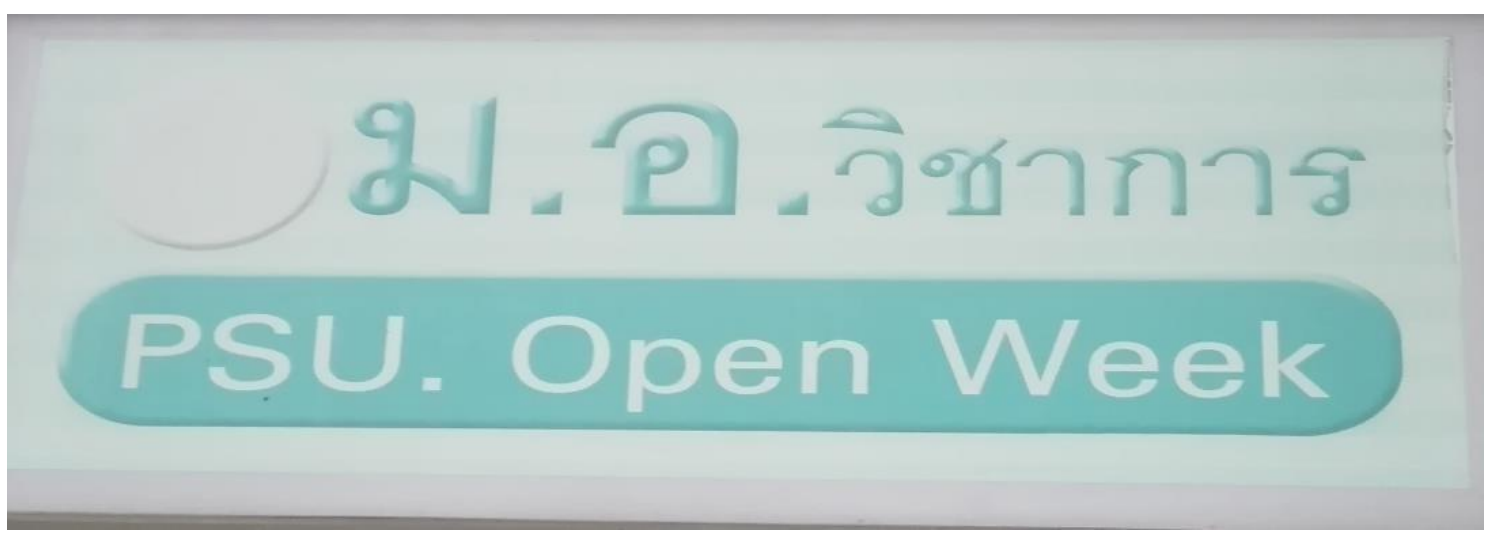

Figure 20. PSU Open Week.

By considering all these variables, the number of signs in which English or Thai were dominant were counted according to the domain (shopping centre, university campus and street), sign type (ads, books, place names, informative signs, etc.) and actor (public or private institutions), to observe the language that was most popular in terms of prominence. The data are presented in the three tables below (See Tables 2, 3 and 4):

Table 2. Language Prominence in Signs according to Domain.

\begin{tabular}{|c|c|}
\hline DOMAIN & LANGUAGE PROMINENCE \\
\hline Central Festival Shopping Centre (43)* & English (54\%)** \\
\hline Prince of Songkla University Campus (41) & Thai (85\%) \\
\hline Vongvanit and Thumnoonvithi Streets (46) & English (53\%) \\
\hline
\end{tabular}

* Total number of multilingual signs in that domain

** Percentage of signs showing that prominent language

According to domain (See Table 3), it can be observed that Thai was the most prominent language in those signs collected from PSU campus, which may suggest that even if it is an international campus hosting students from many other linguistic backgrounds, the LL intends to make explicit the country in which the campus is set in.

Table 3. Language Prominence in Signs according to Sign Categorisation.

\begin{tabular}{|c|c|}
\hline SIGN TYPE & LANGUAGE PROMINENCE \\
\hline Advertisements & English (54\%) \\
\hline Informative signs & Thai (85\%) \\
\hline Product and business names & English (76\%) \\
\hline
\end{tabular}




\begin{tabular}{|c|c|}
\hline Street and Place names & Thai (100\%) \\
\hline Book covers & Thai (73\%) \\
\hline Objects & Thai (100\%) \\
\hline
\end{tabular}

For obvious geographical reasons, Table 3 shows that Thai is the most prominent language in informative signs, street and place names, and objects, since there may be no need to emphasise English for symbolic or media diffusion functions, as it is the case with advertisements, product and business names, and book covers. As far as the actor of the sign is concerned, it is not surprising that Thai is the dominant language in topdown signs and English is chosen by private institutions whose main objective is selling or promoting products and events (See Table 4):

Table 4. Language Prominence in Signs according to Actor.

\begin{tabular}{|c|c|}
\hline ACTOR & LANGUAGE PROMINENCE \\
\hline Public Institution / Top-Down (48) & Thai (90\%) \\
\hline Private Institution / Bottom-Up (82) & English (57\%) \\
\hline
\end{tabular}

In sum, some conclusions can be drawn about the utilisation of English or Thai in signs. On the one hand, it can be stated that Thai is the dominant language in those multilingual signs that perform a more informational function: objects, street and place names and any other informative signs, created by public actors. Consequently, PSU campus is the location with more Thai-dominant signs because these were mostly discovered there. On the other hand, English is the preferred language when dealing with symbolic and media diffusion functions; that is to say, with commercial or business-oriented signs established by private actors, especially advertisements, product packages, and shop signs.

Together with language prominence, another interesting aspect is the amount of text that is devoted to each language in multilingual signs, as all the content of the message is not always provided in both languages.

Regarding Reh's classification of multilingual signs (2004), the four types of multilingual writing that also explore language prominence were also identified in the signs. Prior to this analysis, I had to ask again for translations to Thai speakers. 
- Duplicating Multilingual Writing. The whole content has been fully translated into another language or languages, as in the example below (See Figure 21).

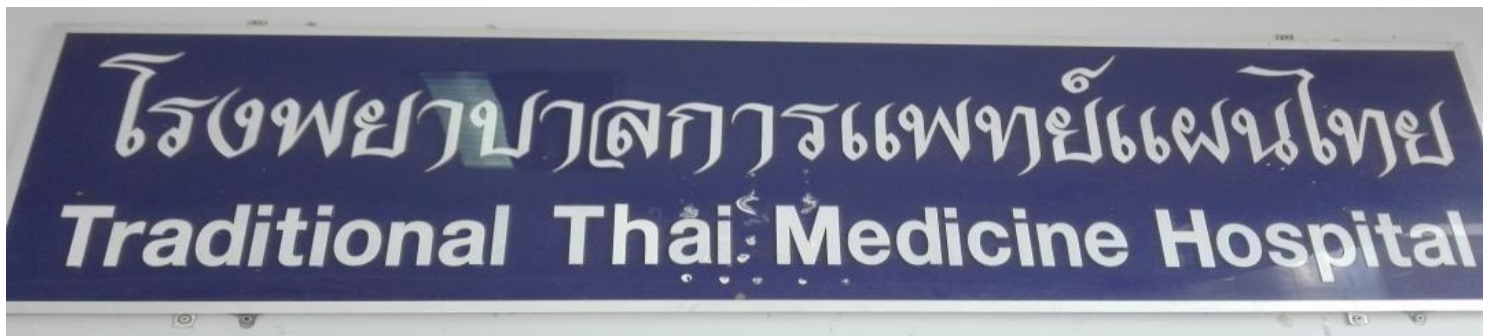

Figure 21. Traditional Thai Medicine Hospital.

- Fragmentary Multilingualism. The whole content of the message is provided in one of the languages, and just some part of it has been translated. In Figure 22, even if the name of the place appears in both English and Thai, the name of the university (in red font) is only written in Thai.

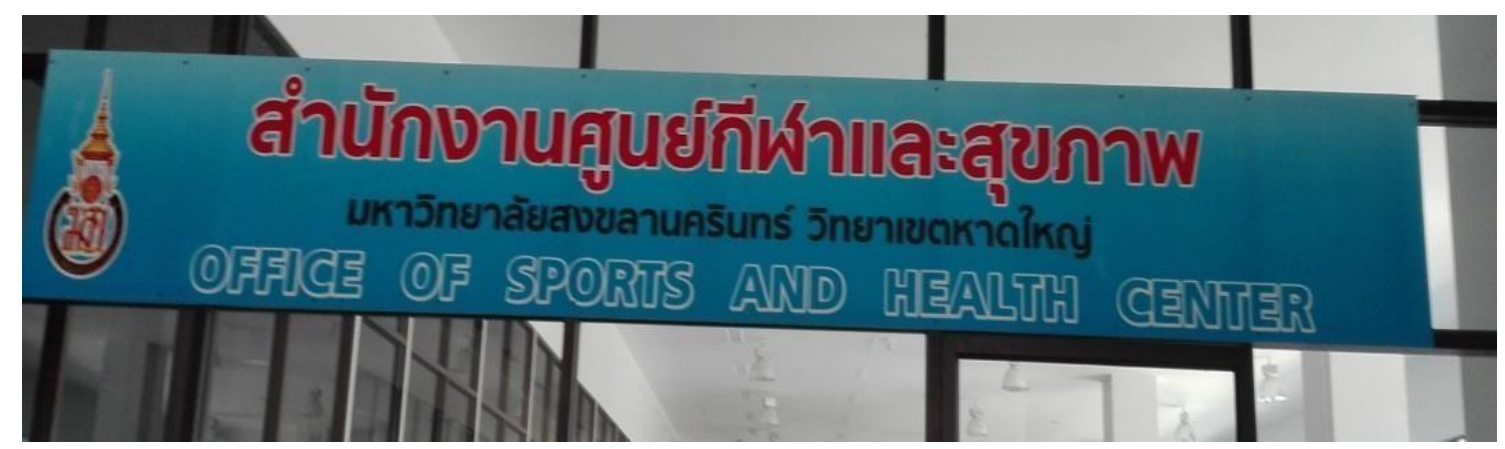

Figure 22. Office of Sports and Health Center.

- Overlapping Multilingual Writing. Two or more languages present shared information in the sign, but each of them also provide other details not found in the other languages. In Figure 23, both languages share some information (the name of the restaurant, "Wooden Box", has been translated into Thai above the arrow); and at the same time, there is some information that each language provides separately: the type of cuisine and drinks in English, and the address of the restaurant in Thai (above the arrow too). 


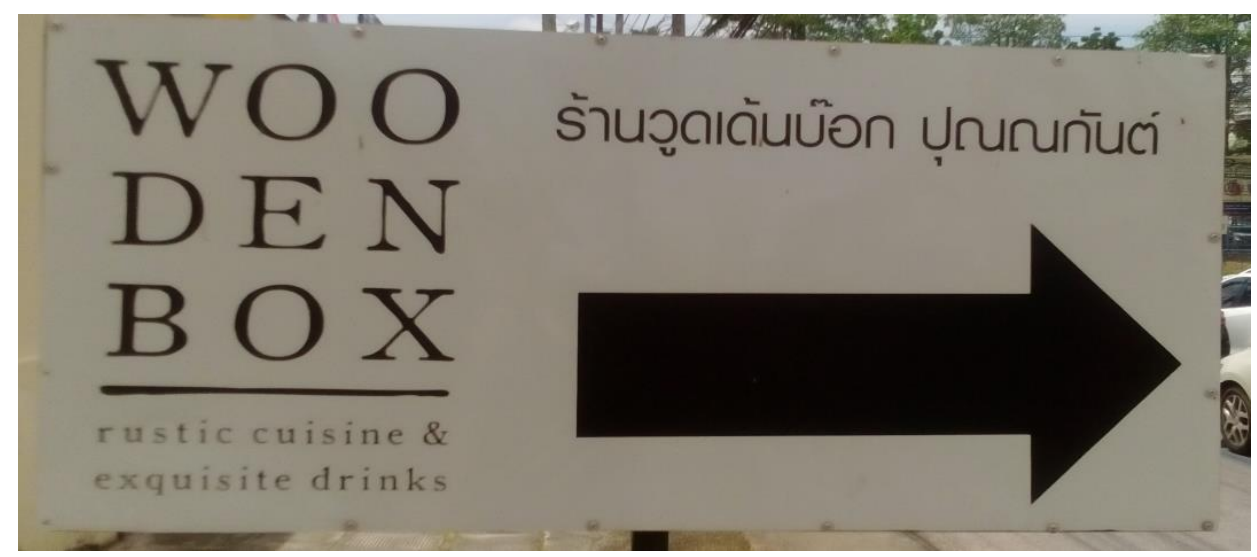

Figure 23. Wooden Box.

- Complementary Multilingual Writing. In this case, two or more languages show different information, as in Figure 24. English covers the slogans of the race, the dates and the city where it will take place, and in the bottom left corner of the sign, the Thai language informs about the exact address and the purpose of the event (learn how to drive a motorcycle in KTM style).

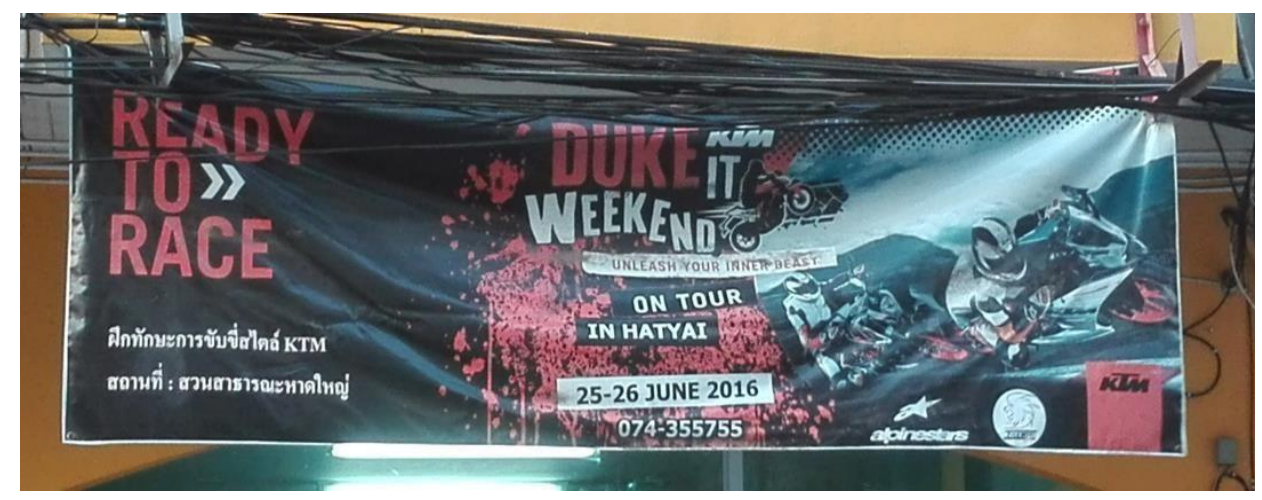

Figure 24. Ready to Race.

Once this classification was made, I proceeded to another quantitative analysis, this time to remark the most common type of multilingual writing according to the sign type. In the sample, 130 out of 165 signs are multilingual. Table 5 demonstrates that the most frequent multilingual signs are duplicating (59 signs), and these can be spotted in informative signs, where the content is meant to be understood by all audiences, local and non-local. 33 signs are fragmentary, 32 complementary and only 6 proved to be 
overlapping. Furthermore, it was interesting to encounter most complementary signs in advertising.

Table 5. Number of Signs for each Multilingual Type according to Sign Type.

\begin{tabular}{|l|c|c|c|c|c|c|c|}
\cline { 2 - 8 } \multicolumn{1}{c|}{} & Adverts & $\begin{array}{c}\text { Informative } \\
\text { signs }\end{array}$ & $\begin{array}{c}\text { Business } \\
\text { and } \\
\text { Products }\end{array}$ & $\begin{array}{c}\text { Streets } \\
\text { and } \\
\text { Places }\end{array}$ & Books & Objects & Total \\
\hline Duplicating & $5^{*}$ & 25 & 13 & 11 & 2 & 3 & $\mathbf{5 9}$ \\
\hline Fragmentary & 8 & 9 & 7 & 1 & 8 & 0 & $\mathbf{3 3}$ \\
\hline Complementary & 23 & 0 & 8 & 0 & 1 & 0 & $\mathbf{3 2}$ \\
\hline Overlapping & 5 & 0 & 1 & 0 & 0 & 0 & $\mathbf{6}$ \\
\hline Total & $\mathbf{4 1}$ & $\mathbf{3 4}$ & $\mathbf{2 9}$ & $\mathbf{1 2}$ & $\mathbf{1 1}$ & $\mathbf{3}$ & $\mathbf{1 3 0}$ \\
\hline
\end{tabular}

* Number of signs in each type.

As it can be distinguished, the amount of information written or translated in English is related to the functions that the English language performs in public signage.

When it comes to business, product names, and titles of events, English is the preferred language in multilingual signs, whether they are translated into Thai (not very usual in this sample) or not. This LL behaviour seems comprehensible enough when considering the symbolic and media diffusion functions discussed previously: the English language allows a rapid diffusion in the case of events, and at the same time, makes the business or products sound reliable, trendy and prestigious. As for the use of English in the promotion and discount signs, it may serve as both a pole of attraction for tourists, and a medium to associate the business with the Western world.

With regards to the Thai language, it is used to provide further information about those companies, products, events, or promotions that have gained more prestige with the use of the international language. Here, the informational purpose of the Thai language in signs is confirmed again. In short, English creates international visibility, and Thai communicates with local people.

\section{IV.4. Thai English}


When carrying out the previous quantitative and qualitative analysis, I remarked that a quarter of the signs did not adopt any specific standard variety of English, such as the American or the British. Instead, some Thainess was revealed in the morphology, syntax and lexicon, which have been previously described as typical features of Thai English or Tinglish (Snodin, 2014; Thammawan, 2008; Trakulkasemsuk, 2012). Chutisilp (1984) and Watkhaolarm (2005) were also pioneers in analysing Thai English writing and concluding that this may be a new developing variety of World Englishes.

As in these previous studies, the LL of Hat Yai shows that even if at a very early stage of development, ThaiE is displayed publicly: $27 \%$ of the signs (44 out of 165) show some features. As it can be noticed in Tables 6, 7 and 8, ThaiE is mostly used in Central Festival and informative signs, with no significant difference among the authors: $28 \%$ were produced by public actors and $25 \%$ in the case of private.

Table 6. Incidence of Signs Written in AE/BE or Tinglish according to Domain.

\begin{tabular}{|c|c|c|}
\hline Domains & $\begin{array}{c}\text { \% Monolingual signs written } \\
\text { in American English (AE) / } \\
\text { British English (BE) or } \\
\text { multilingual signs written in } \\
\text { AE/BE and other languages }\end{array}$ & $\begin{array}{c}\text { \% Monolingual signs written } \\
\text { in ThaiE and Multilingual } \\
\text { signs written in ThaiE and } \\
\text { other languages }\end{array}$ \\
\hline Central & $64 \%$ & $36 \%$ \\
\hline PSU Campus & $73 \%$ & $27 \%$ \\
\hline Streets & $82 \%$ & $18 \%$ \\
\hline
\end{tabular}

Table 7. Incidence of Signs Written in AE/BE or Tinglish according to Sign Type.

\begin{tabular}{|c|c|c|}
\hline Sign type & $\begin{array}{c}\text { \% Monolingual signs written } \\
\text { in American English (AE) / } \\
\text { British English (BE)or } \\
\text { multilingual signs written in } \\
\text { AE/BE and other languages }\end{array}$ & $\begin{array}{c}\text { \% Monolingual signs written } \\
\text { in ThaiE and Multilingual } \\
\text { signs written in ThaiE and } \\
\text { other languages }\end{array}$ \\
\hline Informative & $65 \%$ & $35 \%$ \\
\hline Book covers & $67 \%$ & $33 \%$ \\
\hline Advertisement & $69 \%$ & $31 \%$ \\
\hline Streets & $76 \%$ & $24 \%$ \\
\hline Product & $83 \%$ & $17 \%$ \\
\hline
\end{tabular}




\begin{tabular}{|c|c|c|}
\hline Objects & $100 \%$ & $0 \%$ \\
\hline
\end{tabular}

Table 8. Incidence of Signs Written in AE/BE or Tinglish according to Actor.

\begin{tabular}{|c|c|c|}
\hline Actor & $\begin{array}{c}\text { \% Monolingual signs written } \\
\text { in American English (AE) / } \\
\text { British English (BE)or } \\
\text { multilingual signs written in } \\
\text { AE/BE and other languages }\end{array}$ & $\begin{array}{c}\text { \% Monolingual signs written } \\
\text { in ThaiE and Multilingual } \\
\text { signs written in ThaiE and } \\
\text { other languages }\end{array}$ \\
\hline Public & $72 \%$ & $28 \%$ \\
\hline Private & $75 \%$ & $25 \%$ \\
\hline
\end{tabular}

From these data, it can be concluded that ThaiE is used by Thai population to some extent, no matter the producer or the reader. Even if some consider it "abhorrent" and "not counted" (Bennui \& Hashim, 2014, p.16) or simply do not regard it as a "stabilised form" (Buripakdi, 2011, p.73), the LL of Hat Yai demonstrates that ThaiE is showing some features, to be exemplified below.

- Lexical Borrowing. Some concepts have no translation or simply cannot be explained in other varieties of the English language. Consequently, loans from Thai are detected in ThaiE (See Figure 25).

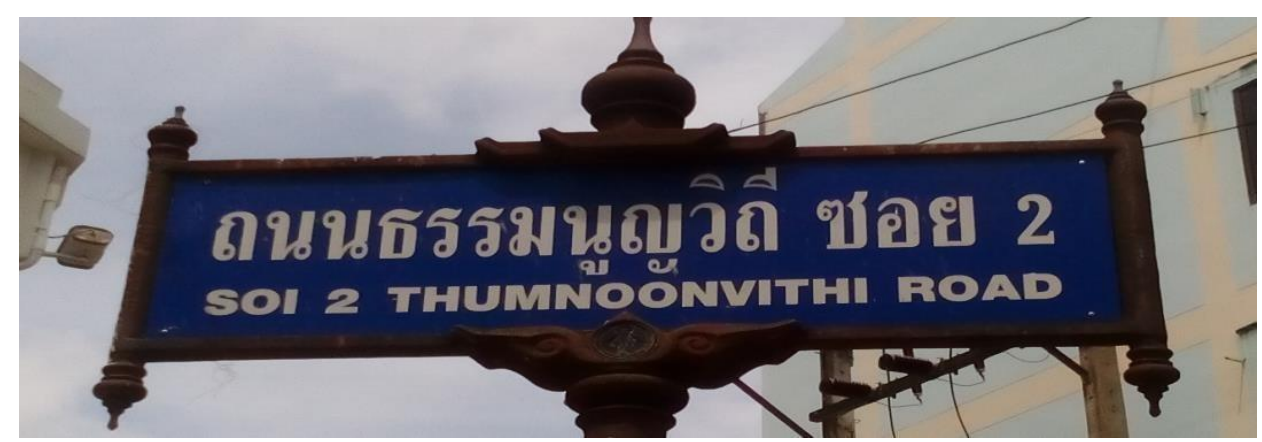

Figure 25. Street name.

In Figure 25, the word "soi" is the Thai word used to refer to a side street that branches off a main bigger street. It is interesting how the word "road" is translated into English, but not "soi", probably because there is no exact translation for it (streets in Thailand are organised in a different way with respect to other countries). 
- Word Order. The natural word-order in Thai is different from English.

For instance, adjectives in English are normally placed before the noun, whereas in Thai, the usual behaviour is exactly the opposite. Because of this, it is common to find the Thai grammatical order in ThaiE (See Figures 30 and 31).

If any variety from the inner circle of World Englishes were used in these signs, the message in Figures 26 and 27 shall be "all beautiful things" and "1st Floor" respectively, but the sentence structure reveals a Thai producer.

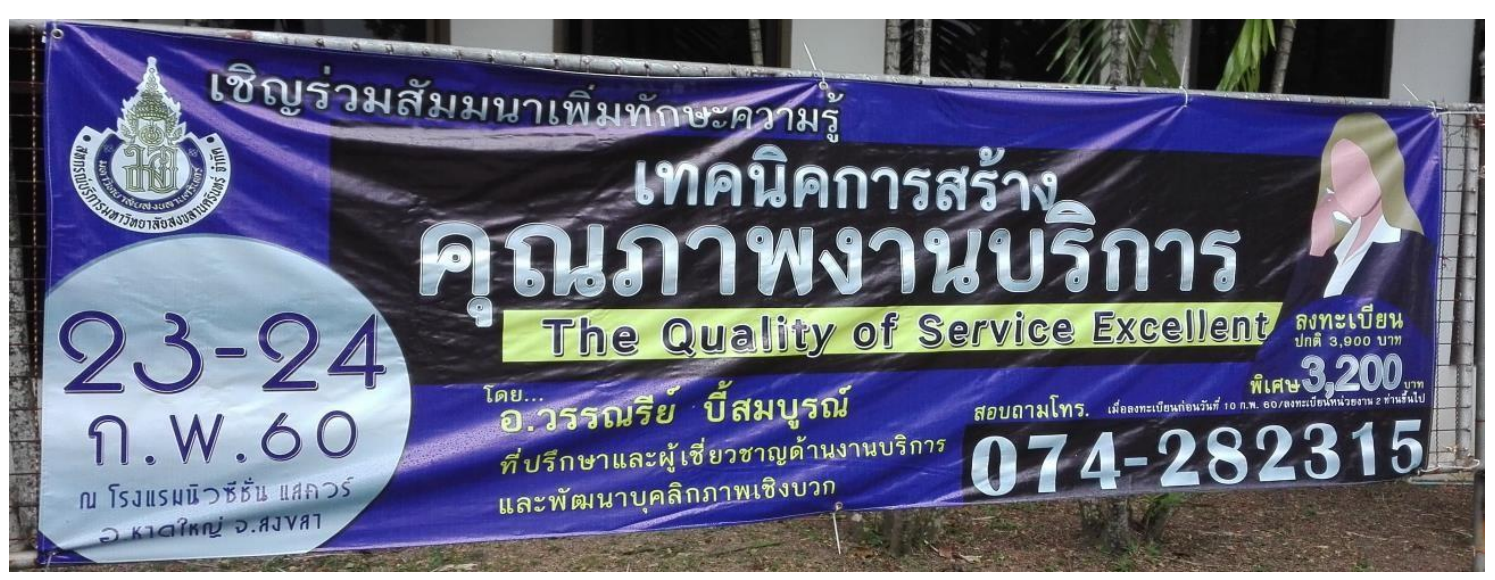

Figure 26. The Quality of Service Excellent Billboard.

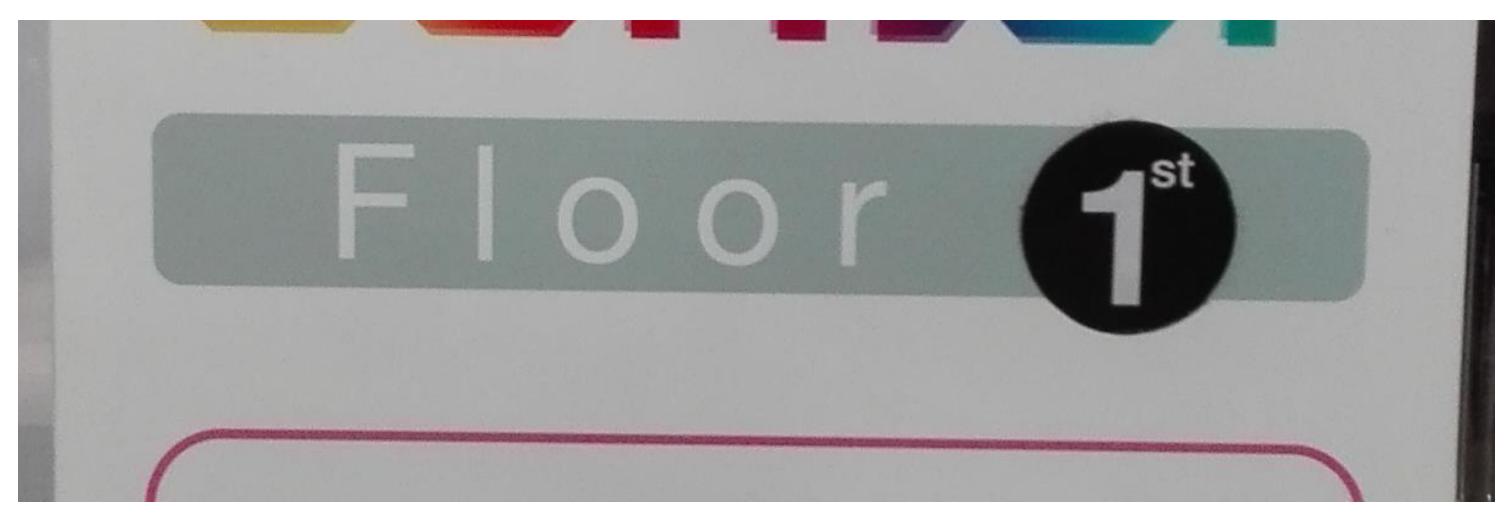

Figure 27.Tourist Center Sign.

- $\quad$ Redundancy. As Trakulkasemsuk (2012) explains, the proper Thai language writing aims to comprise as much information as possible into a sentence, which is why using many modifiers around a noun to provide full explanations is a natural linguistic behaviour and "embellishes" 
English in the linguistic landscape of Thailand: A case study of public signs in Hat Yai

language (p.108). As a result of the transfer of Thainess into English, some redundant structures can be found in signs (See Figures 28, 29 and $30)$.

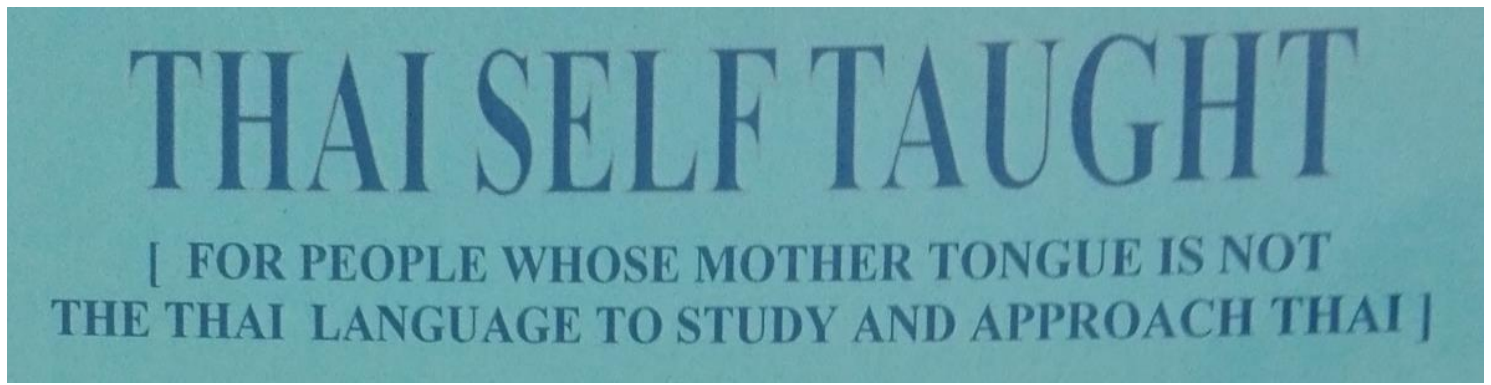

Figure 28. Thai Self Taught Book.

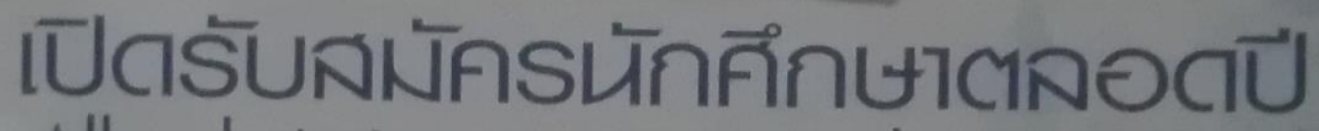 All admissions are opened year round http://wwww.grad.psu.ac.th}

Figure 29. Faculty of Environmental Management Ad.

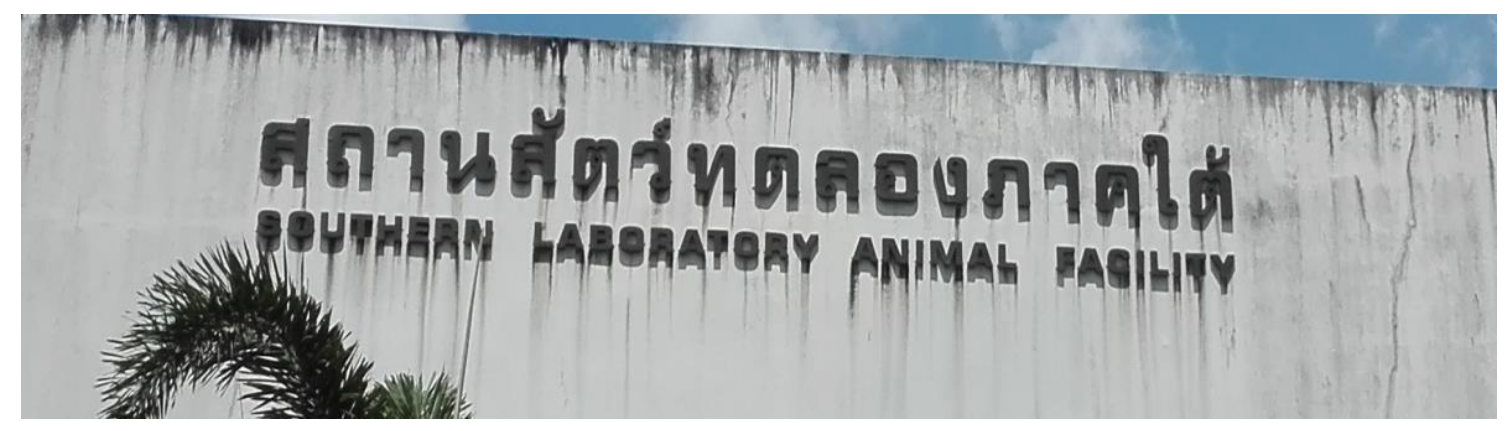

Figure 30. Southern Laboratory Animal Facility.

In Figure 28, the sentence "For people whose mother tongue is not the Thai language to study and approach Thai" sounds definitely wordy and complex in the inner circle varieties of English. The same occurs in Figure 29, where the announcement "All admissions are opened year round" could be simplified to something like "Open admissions year round". As for Figure 30, Kathleen Nicoletti (a New Yorker professor 
from $P S U$ ) and I agreed that the term "facility" is not necessary to designate this place; moreover, it also proves that ThaiE word order is influenced by the Thai language grammatical structure, for the standard grammatical order in English would produce something like "Southern AnimalLaboratory".

- $\quad$ Creative Spelling. In her article, Snodin (2014) mentions the linguistic creativity and originality of the Thai LL actors in the media when dealing with spelling. To illustrate that, she points at the English names of two Thai media shows where the spelling is different than expected: "Klear" and "Dezember" (p.109).

In this sample, I encountered a few cases in which this behaviour could be regarded, and the most repetitive was the spelling of "Beauty" with "i" in cosmetic products (See Figures 31 and 32).

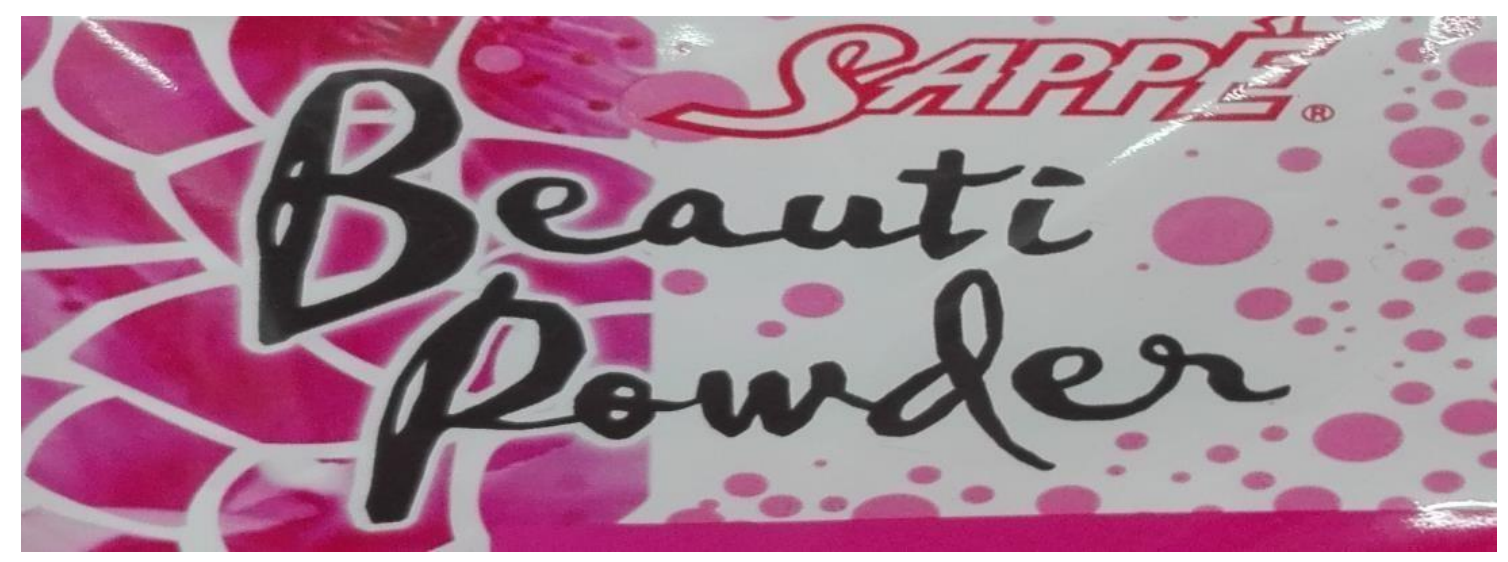

Figure 31. Beauti Powder Product.

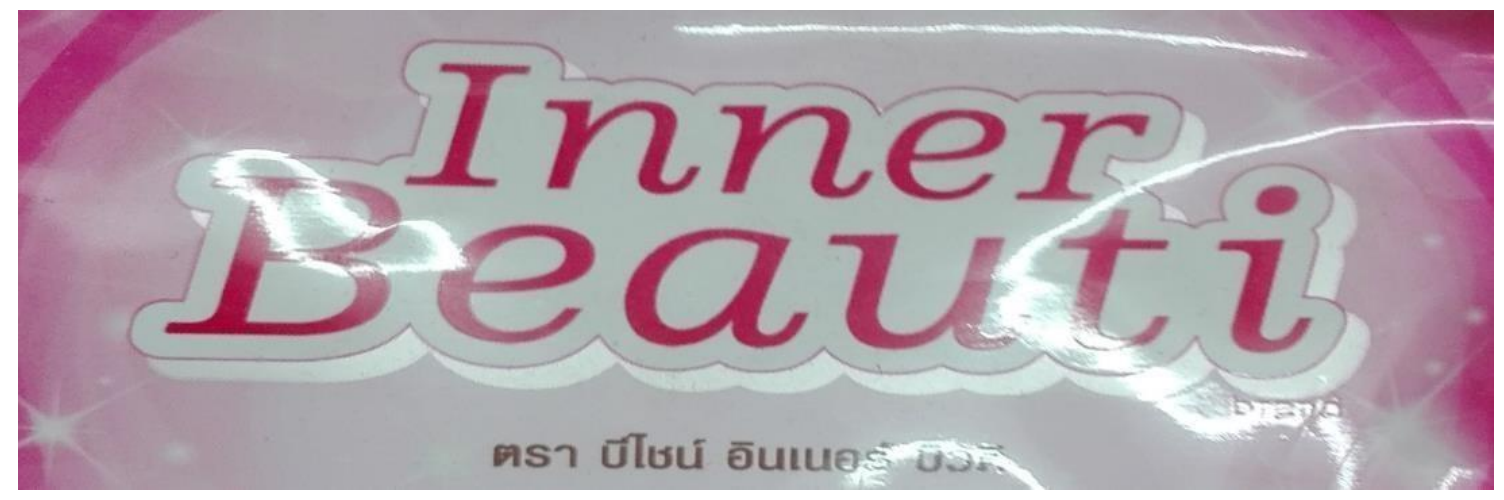

Figure 32. Inner Beauti Product. 
- $\quad$ No Verb Inflection. As explained by Thammawan, the Thai language uses no verb inflections to indicate tenses as in the English language; instead, tenses are expressed by temporal adverbs (2008). For this reason, some verbs do not include verb inflections that would be used in other English varieties, as "Recommend" in Figure 33 and "close" in Figure 34:

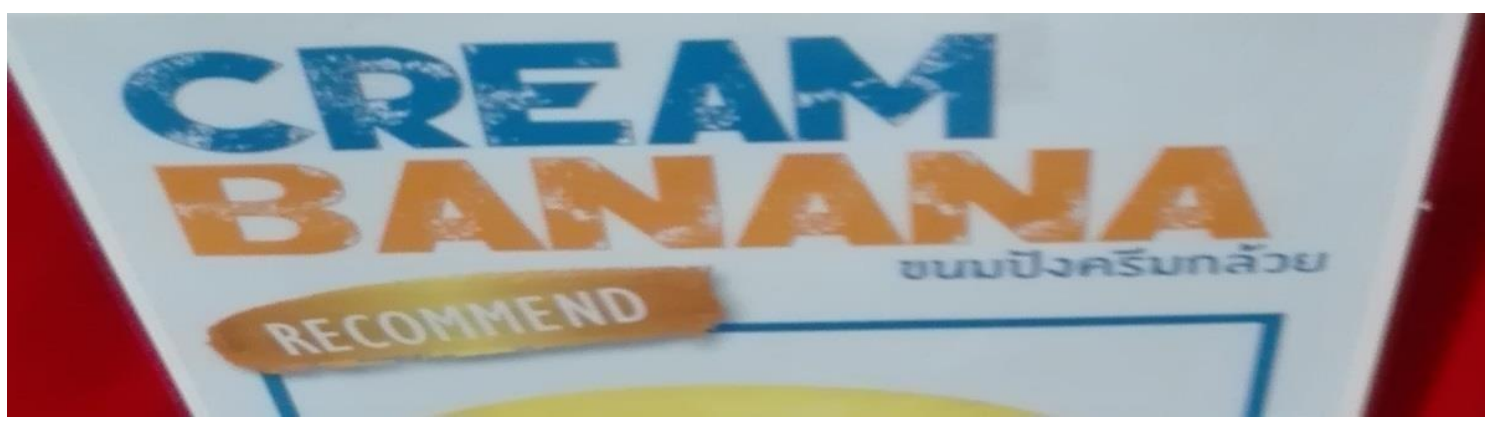

Figure 33. Cream Banana Product.

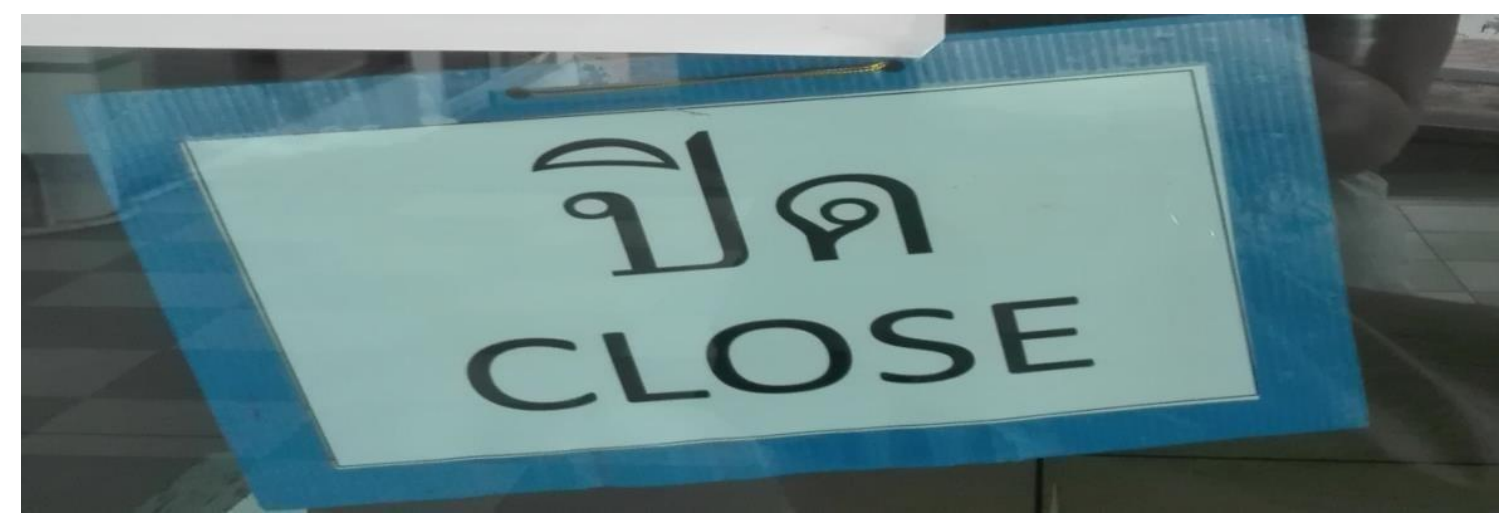

Figure 34. Close Informative Sign.

These are some illustrations of the most evident features of Thai English in this sample of signs. The fact that these features are present in advertising, product packaging, book covers and business names, where the message is intended to have diffusion, suggests that this potential variety of World Englishes may be spreading, and as a result, could become a regularised variety in the future. 


\section{CONCLUSIONS}

In a city where local citizens prove to have very little or no knowledge of English, the LL demonstrates the influence that this language has over the country of Thailand. Whether people use it or not in their daily life, English is present everywhere through public signs, especially in the advertising field.

According to the present corpus, the main functions that English performs in public signs are symbolic, informational and media diffusion, being the first two the most representative. These results demonstrate the effects of an increasingly globalised world, where even in a country like Thailand, whose national language and culture have been strongly preserved along history, the use of English in publicity or business affairs provides an air of westernisation, attractiveness, modernity and reliability, and makes communication easier all over the world.

Regarding language prominence, this analysis shows that English is the dominant language in those signs whose functions are symbolic and media diffusion, and Thai is more visible in informational signs created by public actors. Moreover, English is the preferred language for names of events, promotions, companies and products because of the its positive connotations, and Thai provides further information about those items. Otherwise speaking, English is used to indicate internationalisation and create visibility, and Thai communicates with local people and symbolises local allegiance.

The presence of ThaiE or Tinglish features in a quarter of this corpus was an unexpected but worth mentioning finding that may confirm the early stage of development of a potential variety of World Englishes. In order to draw further conclusions about the position of ThaiE in the next decades, future research will need to be conducted to observe its evolution.

\section{ACKNOWLEDGEMENTS}

I would like to thank Mr Ronnapath Pangoat, Mr. Worradorn Phairuang, Professor Premin Karavi, Professor Kathleen Nicoletti and Ms Ana Maria Pavel, all staff members and students of Prince of Songkla University in Hat Yai, Thailand, for helping me with the translations from English to Thai and vice versa. 
This article is a contribution to the research group "Comunicación internacional y retos sociales" funded by the Regional Government of Aragon (project code H16_20R).

\footnotetext{
Notes

${ }^{\mathrm{i}}$ Association of Southeast Asian Nations (ASEAN), an intergovernmental organisation founded in 1967.

ii Association of Southeast Asian Nations Plus Three (ASEAN + 3) was institutionalised in 1999 and it consists of a cooperation on energy, transport and technology between ASEAN and three other countries: Japan, China and South Korea.

iii Soi: alley, lane or side street.

iv Tambon: sub-district

${ }^{v}$ Amphoe: minor district

${ }^{\text {vi }}$ Changwat: province (http://www.thai-language.com/dict)

vii The population in this South-Eastern region in Thailand is $80 \%$ Malay Muslim who speak Jawi, a Malay dialect, and due to cultural contrasts, have chosen to be resistant to the strong Buddhist Thai pressure. Consequently, major disputes are still taking place between the Thai government and these inhabitants, who have been claiming independence since 1902 (Croissant \& Trinn, 2009, p. 17).

viii The Thai language is read from left to right, which is why this reasoning about left- right language prominence makes sense.
}

\section{REFERENCES}

Amer, F., \& Obeidat, R. (2014). Linguistic Landscape: A Case Study of Shop Signs in Aqaba City, Jordan. Asian Social Science, 10(18), 246-252. http://dx.doi.org/10.5539/ass.v10n18p246

Backhaus, P. (2006). Multilingualism in Tokyo: A look into the Linguistic Landscape. International Journal of Multilingualism, 3(1), 52-66. https://doi.org/10.1080/14790710608668385

Backhaus, P. (2007). Linguistic Landscapes: A Comparative Study of Urban Multilingualism in Tokyo. Clevedon: Multilingual Matters.

Baker, W. (2012). English as a Lingua Franca in Thailand: Characterisations and Implications. Englishes in Practice, 1, 18-27. 
Bennui, P., \& Hashim, A. (2014). English in Thailand: development of English in a nonpostcolonial context. Asian Englishes, 16(3), 209-218. https://doi.org/10.1080/13488678.2014.939810

Ben-Rafael, E., Shohamy, E., Amara, M.H., \& Trumper-Hecht, N. (2006). Linguistic Landscape as Symbolic Construction of the Public Space: The Case of Israel. International Journal of Multilingualism, 3(1), 7-30. https://doi.org/10.1080/14790710608668383

Bierma, H. (2008). Linguistic landscaping in Fryslân. Construction of the commercial linguistic landscape of Franeker. [Master's Thesis, University of Amsterdam]. University of Amsterdam.

Bolton, K. (2008). English in Asia, Asian Englishes, and the Issue of Proficiency. English Today, 94, 3-12. https://doi.org/10.1017/S026607840800014X

Bolton, K. (2012). World Englishes and linguistic landscapes. World Englishes, 31(1), 30-33. https://doi.org/10.1111/j.1467-971X.2011.01748.x

Buripakdi, A. (2011). Thai Journalists' View on the Notion of World Englishes. The Journal of English as an International Language, 6(1), 59-88.

Chutisilp, P. (1984). A Sociolinguistic Study of an Additional Language: English in Thailand. [PhD dissertation, University of Illinois]. University of Illinois.

Coulmas, F. (2013). Writing and Society. An Introduction. Cambridge: Cambridge University Press.

Croissant, A., \& Trinn, C. (2009). Culture, Identity and Conflict in Asia and Southeast Asia. ASIEN The German Journal of Contemporary Asia, 110, 13-43.

Dressler, R. (2015). Signgeist: promoting bilingualism through the linguistic landscape of school signage. International Journal of Multilingualism, 12(1), 128-145. https://doi.org/10.1080/14790718.2014.912282

Flammia, M., \& Saunders, C. (2007). Language as power on the Internet. Journal of the American Society for Information Science and Technology, 58(12), 1899-1903. https://doi.org/10.1002/asi.20659 
Gorter D. (Ed.). (2006). Linguistic Landscape. A New Approach to Multilingualism. Clevedon: Multilingual Matters.

Haynes, P. (2012). Welsh Language Policy: A Study of the Linguistic Landscape at Cardiff University. [Master Dissertation, University of Birmingham]. University of Birmingham.

Huebner, T. (2006). Bangkok's Linguistic Landscapes: Environmental Print, Codemixing and Language Change. International Journal of Multilingualism, 3(1), 31-51. https://doi.org/10.1080/14790710608668384

Kachru, B. (1985). Standards, codification and sociolinguistic realism: the English language in the outer circle. In. R. Quirk and H.G. Widowson (Eds.), English in the world: Teaching and learning the language and literatures (pp.11-30). Cambridge: Cambridge University Press.

Kachru, B. (1998). English as an Asian Language. Links \& Letters, 5, 89-108.

Karapalo, J. (2011). English in the Linguistic Landscape of Tampere: Studying the Visible Process of Macroacquisition. [Postgraduate Thesis, University of Tampere]. University of Tampere

Landry, R., \& Bourhis, R. Y. (1997). Linguistic Landscape and Ethnolinguistic Vitality. An Empirical Study. Journal of Language and Social Psychology, 16(1), 23-49. https://doi.org/10.1177/0261927X970161002

Lawrence, C.B. (2012). The Korean English linguistic landscape. World Englishes, 31(1), 70-92. https://doi.org/10.1111/j.1467-971X.2011.01741.x

Mensel, L.V., Vandenbroucke, M., \& Blackwood, R. (2016). Linguistic Landscapes. In O. García, N. Flores, and M. Spotti (Eds.), The Oxford Handbook of Language and Society (pp.423-450). Oxford: Oxford University Press.

Prasert, K., \& Zilli, P. J. (2019). A linguistic landscape analysis of Pattaya, Thailand's sin city. Discourse and Interaction, 75-95. https://doi.org/10.5817/DI2019-1-75

Reh, M. (2004). Multilingual writing: A reader-oriented typology with examples from Lira Municipality". International Journal of the Sociology of Language, 170, 141. https://doi.org/10.1515/ijsl.2004.2004.170.1 
Siricharoen, A. (2016). Multilingualism in the Linguistic Landscape of the Faculty of Arts, Chulalongkorn University, Thailand. Journal of Humanities, Special Issue, 22, 12-25. https://doi.org/10.1163/26659077-01903002

Shohamy, E., \& Gorter. D. (Eds.). (2009). Linguistic Landscape. Expanding the Scenery. New York, NY: Routledge.

Shohamy, E., Ben-Rafael, E., \& Barni, M. (Eds.). (2010). Linguistic Landscape in the City. Bristol: Multilingual Matters.

Snodin, N.S. (2014). English naming and code-mixing in Thai mass media. World Englishes, 33(1), 100-111. https://doi.org/10.1111/weng.12071

Spolsky, B., \& Cooper, R. (1991). The Languages of Jerusalem. Oxford: Clarendon Press.

Takhtarova, S.S., Kalegina, T.E. \& Yarullina, F.I. (2015). The role of English in shaping the linguistic landscape of Paris, Berlin and Kazan. Procedia - Social $\begin{array}{llll}\text { and Behavioral } & \text { Sciences, }\end{array}$ https://doi.org/10.1016/j.sbspro.2015.07.531

Thammawan, S. (2008). A study of the differences of some grammatical structures of English and Thai that cause English speaking problems for Thai people. [Master Dissertation, University of Thammasat]. University of Thammasat.

Thongton, T. (2016). A Linguistic Landscape Study of Signage on Nimmanhemin Road, A Lanna Chiang Mai Chill-Out Street. Manusya: Journal of Humanities, 19 83), 72-87. https://doi.org/10.1163/26659077-01903006

Trakulkasemsuk, W. (2012). Thai English: An Emerging Variety of World Englishes. In E.L. Louw and A. Hashim (Eds.), Thai English, English in Southeast Asia: Features, Policy and Language in Use. (pp.101-111). Amsterdam: John Benjamins Publishing Company.

Wang, J. (2013). Linguistic Landscape of China: A Case Study of Shop Signs in Beijing. Studies in Literature and Language 6(1), 40-47. http://dx.doi.org/10.3968/j.sll.1923156320130601.1449 
Watkhaolarm, P. (2005). Think in Thai, write in English: Thainess in Thai English Literature. World Englishes, 24(2), 145-158. https://doi.org/10.1111/j.1467971X.2005.00399.x

Wilang, J.D., \& Teo, A. (2012). 2015 Timeline: Birth of Englishes and Varieties within ASEAN. Proceedings of the 4th International Conference on Humanities and Social Sciences (pp.1-19). Thailand: Prince of Songkla University.

Received: 21 March 2020

Accepted: 02 December 2020

Cite this article as:

Vivas-Peraza, A.C. (2020). English in the linguistic landscape of Thailand: A case study of public signs in Hat Yai. Language Value, 13(1), 23-57. Jaume I University ePress: Castelló, Spain. http://www.languagevalue.uji.es.

DOI: http://dx.doi.org/10.6035/LanguageV.2020.13.2

ISSN 1989-7103 